\title{
The parasitoids of the African white rice borer, Maliarpha separatella Ragonot (Lepidoptera: Pyralidae)
}

\author{
Journal Article \\ Author(s): \\ Polaszek, A.; Fitton, M.G.; Bianchi, G.; Huddleston, T. \\ Publication date: \\ 1994 \\ Permanent link: \\ https://doi.org/10.3929/ethz-b-000422572
}

Rights / license:

In Copyright - Non-Commercial Use Permitted

Originally published in:

Bulletin of Entomological Research 84(1), https://doi.org/10.1017/S0007485300032247 


\title{
The parasitoids of the African white rice borer, Maliarpha separatella Ragonot (Lepidoptera: Pyralidae)
}

\author{
A. Polaszek \\ Department of Entomology, Wageningen Agricultural University, \\ The Netherlands/International Institute of Entomology, London, UK \\ M.G. Fitton \\ Department of Entomology, The Natural History Museum, \\ London, UK \\ G. Bianchi \\ Eidgenössische Technische Hochschule, Zurich, Switzerland

\section{T. Huddleston} \\ Department of Entomology, The Natural History Museum, \\ London, UK
}

\begin{abstract}
A key is provided for the recognition of the hymenopterous parasitoids of the African white rice borer, Maliarpha separatella Ragonot, a pest of rice in Africa and Madagascar. Five species are described as new: Braconidae: Chelonus maudae Huddleston, Rhaconotus carinatus Polaszek; Ichneumonidae: Pristomerus bullis Fitton, Pristomerus carls Fitton, Venturia jordanae Fitton. The following synonyms are proposed: Goniozus indicus Muesebeck, G. natalensis Gordh and G. procerae Risbec are synonymized with Goniozus indicus Ashmead. Phanerotoma major Brues is synonymized with Phanerotoma saussurei Kohl. Lectotypes are designated for Goniozus procerae Risbec, Rhaconotus scirpophagae Wilkinson and Garouella ovicida Risbec. The known distributions, biologies and alternative hosts of each parasitoid are provided, and their use as biological control agents or components of integrated pest management programmes are discussed.
\end{abstract}

\section{Introduction}

Maliarpha separatella Ragonot, commonly called the African white rice borer, is known almost exclusively as a

Correspondence: Dr A. Polaszek, Dept of Entomology, Wageningen Agricultural University, P O.B. 8031, $6700 \mathrm{EH}$ Wagenıngen, The Netherlands pest of cultivated rice (Oryza sativa and O. glaberrima). It also occurs on the wild rices $O$. longsstammata and $O$. punctata (Brenière et al., 1962). Apart from Oryza spp. it has been reported only from the wild grasses Andropogon tectorum and Echinochloa holubir (Anon., 1970, 1977).

Maliarpha separatella is distributed throughout subsaharan Africa and Madagascar, and published records from outside these regions (Martin, 1958; CIE, 1970; Sandhu 
\& Chander, 1975, Li, 1985) are of doubtful validity. However, there remain several problems concerning the genus Maliarpha. Taxonomic studies show that in West Africa two Maliarpha spp. may be present, the pan-African (and Madagascan) $M$. separatella, and a second species, possibly undescribed. The possible existence of a second Maliarpha sp. in West Africa was suggested by Viette (in Etienne, 1977), more recently by M. Shaffer (pers. comm.), and by studies of sex pheromones (Cork et al., 1991). The most recent taxonomic treatment of Maliarpha by Martin (1958) is rather cursory and needs careful reassessment in order to establish exactly which species are present, their status and distribution. The biology and ecology of $M$. separatella have been thoroughly reviewed by Brenière et al (1962), Appert (1970), Pollet (1981), Ho et al. (1983) and Bianchi et al. (1990). It is unlikely that any of these studies concern a species other than $M$. separatella itself.

The impact of $M$. separatella on rice yield is difficult to assess because damage to the plant only rarely results in the appearance of 'dead hearts' or 'white heads', which are the most apparent signs of damage by other stem-boring species. Some assessments of yield loss have been undertaken (Pollet, 1981; Ho et al., 1983; Akinsola, 1984; Ho, 1986; Anon., 1989; Baumgärtner et al., 1990; Bianchi et al., in press), but remain neglected for most African and Madagascan rice agroecosystems. As a major pest $M$. separatella is therefore something of a borderline case, but its importance may increase with the intensification of rice production. Control using chemical insecticides has been thoroughly investigated, but is not widely practised because of the high costs involved (Akinsola \& Agyen-Sampong, 1984). Alternative methods are currently being developed, and biological control represents the most economically efficient and ecologically least harmful prevention method.

Biological control of rice stem borers through the introduction of exotic parasitoids has been attempted previously in Madagascar (Appert et al., 1969; Appert, 1970, 1971; Anon., 1975) and Senegal (Rouderllac, 1972, Vercambre, 1977a), as well as in several parts of Asia. In Madagascar parasitoids were usually introduced either from East Africa or from India with the primary intention of controlling stem borers in sugarcane or maize monocultures (Appert et al., 1969; Betbeder-Matibet, 1971). In most cases field testing and release of parasitoids against $M$. separatella were carried out incidentally during other biological control projects, and with natural enemies that probably were not well adapted to $M$. separatella. Often, species were used which had never been reared from $M$. separatella, either from the field or in the laboratory.

Until now there has been no thorough investigation of the natural enemy complex of $M$. separatella. In order to attempt to fill this gap a new research programme was initiated to complete previous surveys in different African and Madagascan rice agroecosystems (Bousses \& Rahalıvavololona, 1990; Bianchi ef al., 1991). These surveys have revealed a large complex of parasitoids associated with this pest, and in order to facilitate correct identification of these parasitoids, and to provide access to information concerning their biology, the current study was initiated.

\section{Methods}

Field work was conducted in Cameroon, Ivory Coast, Kenya, Madagascar, Senegal and Tanzania. Wherever poss- ible, upland, irrigated and flooded rice ecosystems were investigated. Rice stems were collected and dissected for larvae or pupae of $M$ separatella and egg masses were collected from leaves Parasitoids were reared by placing the excised part of the plant containing the apparently parasitized borer larva, pupa or eggs in a small plastic vial kept at $25^{\circ} \mathrm{C}$. After parasitoid emergence head capsules of host larvae were examined to confirm the host's identity. Egg masses of $M$. separatella are distinctive and easily recognizable, even when parasitızed (Brenière et al., 1969, figs 12-14).

The most important previous surveys of $M$. separatella parasitoids were carried out in Ghana (Scheibelreiter, 1972; Agyen-Sampong, 1977) Ivory Coast (Pollet, 1981), Madagascar (Appert, 1973), Senegal (Roudeillac, 1972; Etienne, 1987) and Sierra Leone (Jordan, 1966; Agyen-Sampong, 1980), and a largely successful attempt was made to retrieve all voucher specimens from these surveys. Reared specimens from various insect collections in Europe and Africa were also examined, and this resulted in the discovery that many published records of parasitoids have been based on misidentifications. Six species, belonging to different genera, examined during the current survey were each represented by between one and three specimens only. Positive identification of these as either previously described species or species new to science was not possible, and they have therefore each been designated 'species $A$ ' Material examined is listed only for species newly described and those designated 'species $A^{\prime}$. For previously described species it can be assumed that all material currently present in the collections of the BMNH, MNHN and WAU has been examined. Specimens of all the species in this study are deposited in the collections of The Natural History Museum, London, UK. All abbreviations can be found under Acknowledgments.

Unpublished reports cited in this paper are deposited in the library of the Department of Entomology, Wageningen Agricultural University. The Netherlands.

\section{Key to the parasitoids of $M$. separatella, males and females}

The following key is designed to be used for specimens examıned with a stereo binocular ('dissecting') microscope at magnifications of up to at least $\times 60$ For the correct identification of some species it is necessary to make slide preparations of certain parts of the body for subsequent examination with a compound microscope at higher magnifications. The range of morphological diversity of $M$. separatella parasitoids extends from relatively large species (up to $10 \mathrm{~mm}$ ), such as some Ichneumonidae, down to Trichogrammatidae (less than $1 \mathrm{~mm}$ ), and includes groups from the section Aculeata (Bethylidae) and Parasitica (remaining families). For specimen preparation and morphological terminology the user is therefore referred to Gauld \& Bolton (1988) or Borror et al. (1989).

This key is designed exclustvely for the identification of specimens which are known to have been reared from $M$. separatella. Many of the genera mentioned in this study contain groups of closely related species which attack stem borer pests in Africa and Madagascar. Some of these species attack hosts whose ecology may be very similar to that of $M$. separatella, but are not, as yet, known from $M$ separatella. For this reason it is important that the host is correctly 
Table 1 Checklist of Malarpha separatella parasitoids

\begin{tabular}{|c|c|c|c|}
\hline Genus/species & Family & Subfamily & $\begin{array}{c}\text { Page } \\
\text { reference }\end{array}$ \\
\hline Amauromorpha sp. A & Ichneumonidae & Phygadeuontinae & p 84 \\
\hline Bracon testaceorufatus & Braconıdae & Braconinae & p 77 \\
\hline Chelonus maudae & Braconidae & Cheloninae & p 78 \\
\hline Cotesta ruficrus & Braconidae & Microgastrinae & p 80 \\
\hline Elasmus sp. A & Elasmidae & & p 81 \\
\hline Eurytoma oryzivora & Eurytomidae & Eurytominae & p 82 \\
\hline Goniozus indicus & Bethylıdae & Bethylınae & p 68 \\
\hline Lathromeris ovictda & Trichogrammatidae & & p 85 \\
\hline Macroneura sp A & Eupelmidae & & p 82 \\
\hline Mesobraconotdes psolopterus & Braconıdae & Braconinae & p 78 \\
\hline Norbanus sp. A & Pteromalidae & Pteromalinae & p 84 \\
\hline Phanerotoma saussuret & Braconıdae & Cheloninae & p 79 \\
\hline Pristomerus africator & Ichneumonidae & Cremastınae & p 83 \\
\hline Pristomerus bullis & Ichneumonidae & Cremastinae & p 83 \\
\hline Pristomerus carts & Ichneumonidae & Cremastinae & p 83 \\
\hline Psilochalas soudanensis & Chalcididae & & $\mathrm{p} 81$ \\
\hline Rhaconotus carmatus & Braconidae & Doryctinae & p 79 \\
\hline Rhaconotus scirpophagae & Braconidae & Doryctınae & p 80 \\
\hline Telenomus bint & Scelıonidae & Telenominae & p 85 \\
\hline Temelucha sp. A & Ichneumonidae & Cremastınae & p 83 \\
\hline Tetrastichomyıa sp. A & Eulophidae & Tetrastıchinae & p 81 \\
\hline Tropobracon antennatus & Braconidae & Braconinae & p 78 \\
\hline Vadonina 'nimbipennis & Ichneumonidae & Phygadeuontınae & p 84 \\
\hline Ventura jordanae & Ichneumonidae & Campopleginae & p 82 \\
\hline
\end{tabular}

identified. Reference to the diagnosis or description contained in each species treatment is essential. It is hoped that the authors have succeeded in excluding the possibility of misidentifications by providing diagnoses for previously described species and complete descriptions for new species. In doubtful cases, specimens may be sent to the first author for checking.

In addition to the species known to have been reared from $M$. separatella, two additional species have been included in the key for reasons given below: Ceraphronidae. Aphanogmus fijtensis (Ferrière) and Ichneumonidae: Pimplinae Itoplectis naranyae (Ashmead).

1. Fore wing without closed cells, or brachypterous (figs

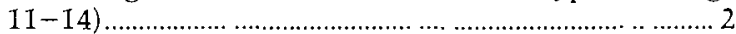
- Fore wing with at least one closed cell (figs 15-17, 33, $34,44-46,65) \ldots \ldots \ldots \ldots \ldots \ldots \ldots \ldots \ldots \ldots \ldots \ldots \ldots \ldots \ldots \ldots \ldots \ldots \ldots \ldots . . .11$

2. Tarsi 3-segmented; antennae with fewer than 8 segments (excluding anellı, fig. 10). Fore wing as in fig. II Lathromeris ovicida

- Tarsi 4- or 5-segmented; antennae with more than 8 segments ...................................................................... 3

3. Pronotum reaching tegulae (fig. 1); prepectus (see fig. 2) absent.

- Pronotum not reaching tegulae, prepectus present between pronotum and tegula (fig. 2) .............................. 5

4. Stigmal vein distinctly curved, fore wing venation as in fig. 12 (hyperparasitoids, emerging from coccoons) Aphanogmus fijensis Fore wing venation different, stigmal vein straight (fig. 13); (egg parasitoids)................................ Telenomus bim

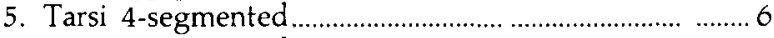

- Tarsi 5-segmented .............................................................. 7

6. Hind coxa greatly expanded and flattened (fig. 3) Elasmus sp. A
- Hind coxa not greatly expanded and flattened ..............................................Tetrastichomyia sp. A

7. Hind femur greatly expanded and toothed (fig. 4) Psilochalcis soudanensis

- Hind femur not greatly expanded or toothed.............. 8

8. Mesopleuron forming a strongly convex shield (fig. 5), brachypterous species ................. Macroneura sp. A (fp)

- Mesopleuron different .................................................... 9

9. Pronotom rectangular in dorsal view, with coarse punctures (fig. 6)....................................Eurytoma oryzivora

- Pronotum different .............................................................. 10

10. Notauli incomplete (fig. 8). Antenna 12-segmented (f), consisting of scape, pedicel, 2 small ring segments, a 6-segmented funicle and a rather obscurely 2-segmented club with a point (fig. 9), $\hat{\jmath}$ unknown, antennae may be 12- or 13-segmented..................Norbanus sp. A

- Notauli complete. Antenna 12-segmented, consisting of scape, pedicel, a single ring segment, 6-segmented funicle and three segmented club without a point Macroneura sp. A $\hat{\jmath} \hat{\jmath}$

11. Hind wing without veins, fore wing venation as in fig. 15; propodeum as in fig. 81 ................. Goniozus indicus -Hind wing with veins, fore wing venation and propodeum different ................................................... 12

12. Fore wing with a single recurrent vein (that is, $2 \mathrm{~m}$-cu absent; figs 16, 17, 33) first cubital cell almost always separated from the discoidal cell by a vein (Braconidae, except Chelonus, fig. 34) .................................................. 13

- Fore wing with two recurrent veins (that is, $2 \mathrm{~m}$-cu present; figs 44-46, 65); first cubital cell always fused with the discoidal cell (Ichneumonidae) .......................20

13. Hypoclypeal depression present, deep and wide (fig. 24)

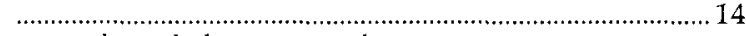

- Hypoclypeal depression absent .................................... 18

14. Posterior flange of propleuron absent; first metasomal tergite coarsely rugose (figs 19,21). Fore tibia without a row of pegs or thick spines.....................................15 
- Posterior flange of propleuron present (figs 28, 31); first metasomal tergite longitudinally striate (figs 29, 32) Fore tibia with a row of pegs or thick spines ......... 17

15. Wings strongly infumate (darkened)

Mesobraconoudes psolopterus

Wings largely hyaline (clear)

I6 Mesosoma entirely orange. Antennae elongate, about $1.25 \times$ the body length (excluding ovipositor). Mesoscutum with fine, reticulate sculpture (fig. 20) Tropobracon antennatus

- Mesosoma with some brown or black markings. Antennae shorter, about equal to, or less than, the body length (excluding ovipositor). Mesoscutum smooth, shining (fig. 18) ................................. Bracon testaceorufatus

17. Pterostigma uniformly pale (fig. 16). Head and mesosoma with dense setae (figs $25,27,28$ )

Rhaconotus sctrpophagae

- Pterostigma dark (fig. 17) at least in its anterior half. Head and mesosoma less densely setose (figs 26, 30, 31) Rhaconotus carmatus

18. Tergites 1-3 of metasoma immovably joined (figs 23 35 ) and forming a carapace. Vein SRI present and enclosing a marginal cell (fig. 34). 19

- Tergites 1-3 of metasoma articulating, not forming a carapace. Vein SR1 absent, and fore wing venation as in fig. 33

. Cotesia ruficrus

19. Body entirely yellow. Tergites of metasoma clearly distingushable (fig. 23) ................ Phanerotoma saussurei - Body largely dark. Metasoma forming an undivided carapace..................................................... Chelonus maudae

20. Segment 1 of the metasoma rather wide, with the spiracles on the anterior half (fig. 39). Edge of eye strongly indented opposite antennal socket (fig. 38) Itoplects naranyae

- Segment 1 of the metasoma more slender (fig. 40), with the spiracles on the posterior half (fig. 42). Edge of eye at most only weakly sinuate opposite antennal socket (fig. 41)

....21

21. Fore wing with pterostigma long and slender (fig. $44-46$ ). Tergite 2 of metasoma granulate or punctate

- Fore wing with pterostigma broad and triangular (fig. 65). Tergite 2 of metasoma very finely, longitudinally aciculate (figs $73-75$ )............................................. 24

22. Clypeus not distinctly separated from face, the two together forming a continuous, weakly convex surface (fig. 66). Fore wing with areolet (absent in a few aberrant specimens) petiolate (2rs-m and 3rs-m arising together from Rs) (fig. 44) .................. Venturia jordanae

- Clypeus separated from face, clypeus and face each forming a distinct, curved surface (figs 67, 68). Fore wing with areolet present and almost quadrate (the sections of Rs and $M$ between 2 rs-m and 3rs-m almost equal in length) (fig. 46) or areolet absent (fig. 45)

23. Fore wing with areolet present, although $3 \mathrm{rs}$-m weakly or not pigmented (fig. 46). Frons with a differentiated trans-striate area above the antennal socket (fig. 67) Vadonina ?nimbipennis

Fore wing with areolet absent (fig. 45), although the position which 3rs-m would occupy may be indicated by the configuration of Rs and M. Frons without a differentiated area (although it is less punctate) above the antennal sockets (fig. 68)....... Amauromorpha sp. A
24. Tergite 2 of metasoma without thyridia. Hind femur of males and females without a tooth on the ventral surface................................................... Temelucha sp A

- Tergite 2 of metasoma with thyridia (figs 73-75). Hind femur of males, but not of all females with a distinct tooth on the ventral surface (figs $62-64$ ).................25

25. Eyes larger in proportion to size of head: face narrower (male fig. 49, female fig. 50), gena (In lateral view) narrower (male fig. 58, female fig. 55). Male with ocelli not quite touching eyes (fig. 60). Female with hind femur lacking a distinct tooth on ventral surface (fig. 61)

Pristomerus caris

- Eyes smaller in proportion to size of head: face wider (male figs 47,48 , female figs 51, 52), gena (in lateral view) wider (male figs 56, 57, female figs 53,54). Male with ocelli separated from eyes by more than 0.6 of their diameter (fig. 59). Female with hind femur with a distinct tooth on ventral surface (fig. 62) ..................26

26. Clypeus wider and less convex (male fig. 47 , female fig. 51). Female with ovipositor shorter, less than 1.9 (the visible portion 1.3) times as long as the hind tibia. Male with hind femur stouter (fig. 63) [East Africa] Pristomerus bullis Clypeus narrower and more convex (male fig. 48, female fig. 52). Female with ovipositor longer, more than 2.3 (the visible portion 1.4) times as long as the hind tibia. Male with hind femur more slender (fig. 64) [West Africa] ................................... Pristomerus africator

\section{BETHYLIDAE}

\section{Goniozus indicus Ashmead \\ (figs 15, 78, 79, 81)}

Gonozus inducus Ashmead, 1903: 2 Holotype + , India Calcutta [ex Scirpophaga] (USNM) [examined].

Gonozus mdicus Muesebeck, 1940. 121. Holotype $\mp$, INDIA Combatore V.2636 (P. Israel) ex Scrpophaga on sugarcane (USNM) [examined] syn. nov.

Gonozus procerae Rısbec, 1956b. 157 Lectotype \& (here designated), [CAMEROON] Garoua (Descamps 173) (MNHN) [examuned] syn. nov.

Gonozus natalensis Gordh, 1986: 257 Holotype ₹, SOUTH AFRICA: Natal, Ngwavuma 20.xı 1982 (H. Hastings) ex Eldana saccharna (PPRI) [holotype not examined; paratypes examined] syn. nov.

Gonozus sp Descamps, 1956, Harrı, 1962, Jordan, 1966, Appert, 1973; Agyen-Sampong, 1980; Agyen-Sampong \& Fannah, 1987

Diagnosis. Length $3.0-6.0 \mathrm{~mm}$ Entirely chestnut brown to black, with the following usually paler antennae, all tibiae and tarsı, fore femora. Head prognathous as in all Bethylidae, body appreciably dorso-ventrally flattened. Head ( $\left(^{\prime}\right)$ in dorsal view elongate, distance from the hind margin of the eyes to the posterior end of the head slightly greater than the maximum length of the eyes Ocell forming an approximately equilateral triangle, separated from the posterior end of the head by about the maximum length of the ocellar triangle Clypeus evenly rounded, not pointed or truncate Sculpture of the head and body smooth, shining, with a few shallow punctures Fore femora enlarged. Fore wing typical for the genus (fig. 15), with both pterostigma and prostigma present, without a closed areolet Propodeum without any trace of a transverse carina separating the dorsal (horizontal) surface from the posterior (vertical) surface; with fine, reticulate sculpture apart from 

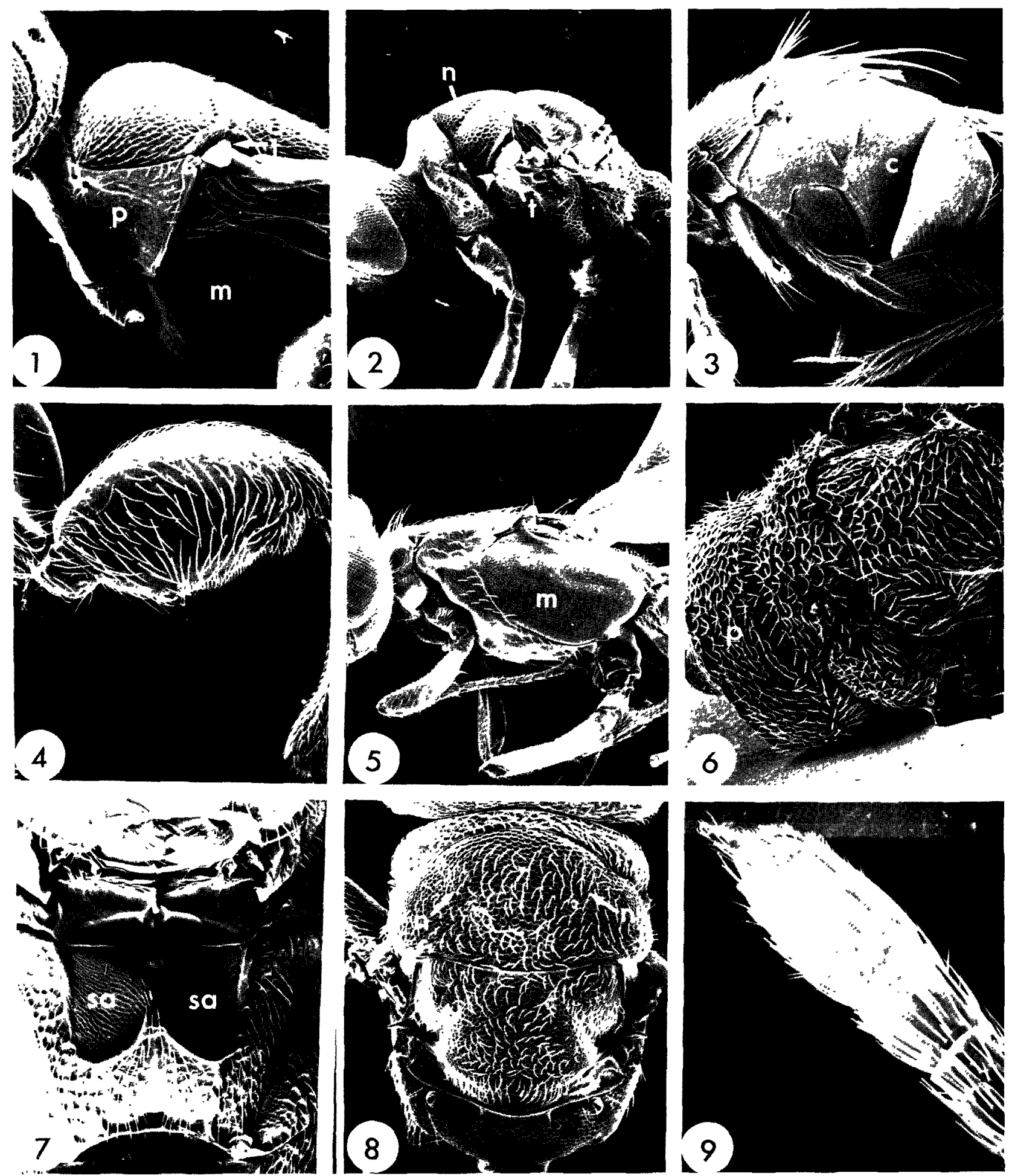

Figs 1-9. 1, Aphanogmus finensis mesosoma, lateral $(\mathrm{m}=$ mesopleuron, $p=$ pronotum, $t=$ tegula $)$; 2 , chalcidoid mesosoma, lateral $(\mathrm{p}=$ prontotum, $\mathrm{t}=$ tegula); 3, Elasmus sp. mesosoma, lateral $(\mathrm{c}=$ hind coxa); 4, Psilochalcis sodanensis hind femur; 5 , eupelmid $(\mathrm{f})$ mesosoma, lateral $(\mathrm{m}=$ mesopleuron); 6, Eurytoma oryzivora mesosoma, dorsal $(\mathrm{p}=$ pronotum); 7 , E. oryzivora mesosoma, ventral (sa $=$ subpleural area); 8. Norbants sp mesosoma, dorsal $(n=$ notauli); 9 , Norbanus sp ( 1$)$ antennal club 


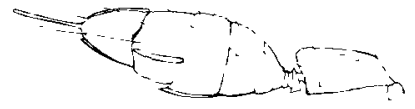

10
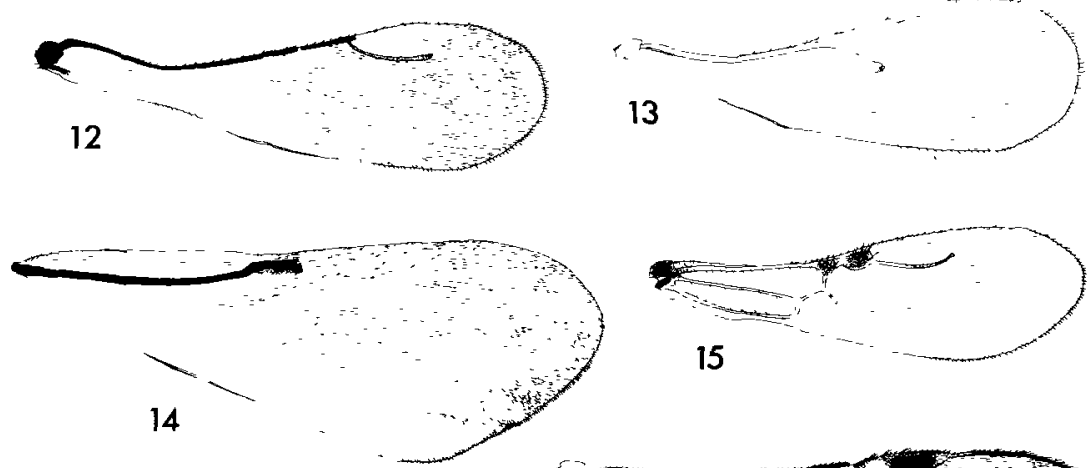

15

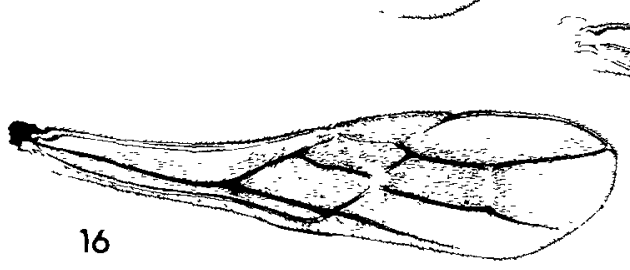

11 $+x^{*}$

Figs 10-17. 10, Lathromeris ovtcida antenna; 11, L ovtuda fore wing; 12, Aphanogmus finensis fore wing; 13, Telenomus binl fore wing; 14, Psilochalcis soudanensis fore wing; 15, Gonozus indicus fore wing; 16, Rhaconotus scirpophagae fore wing; 17, Rhaconotus carmatus fore wing.
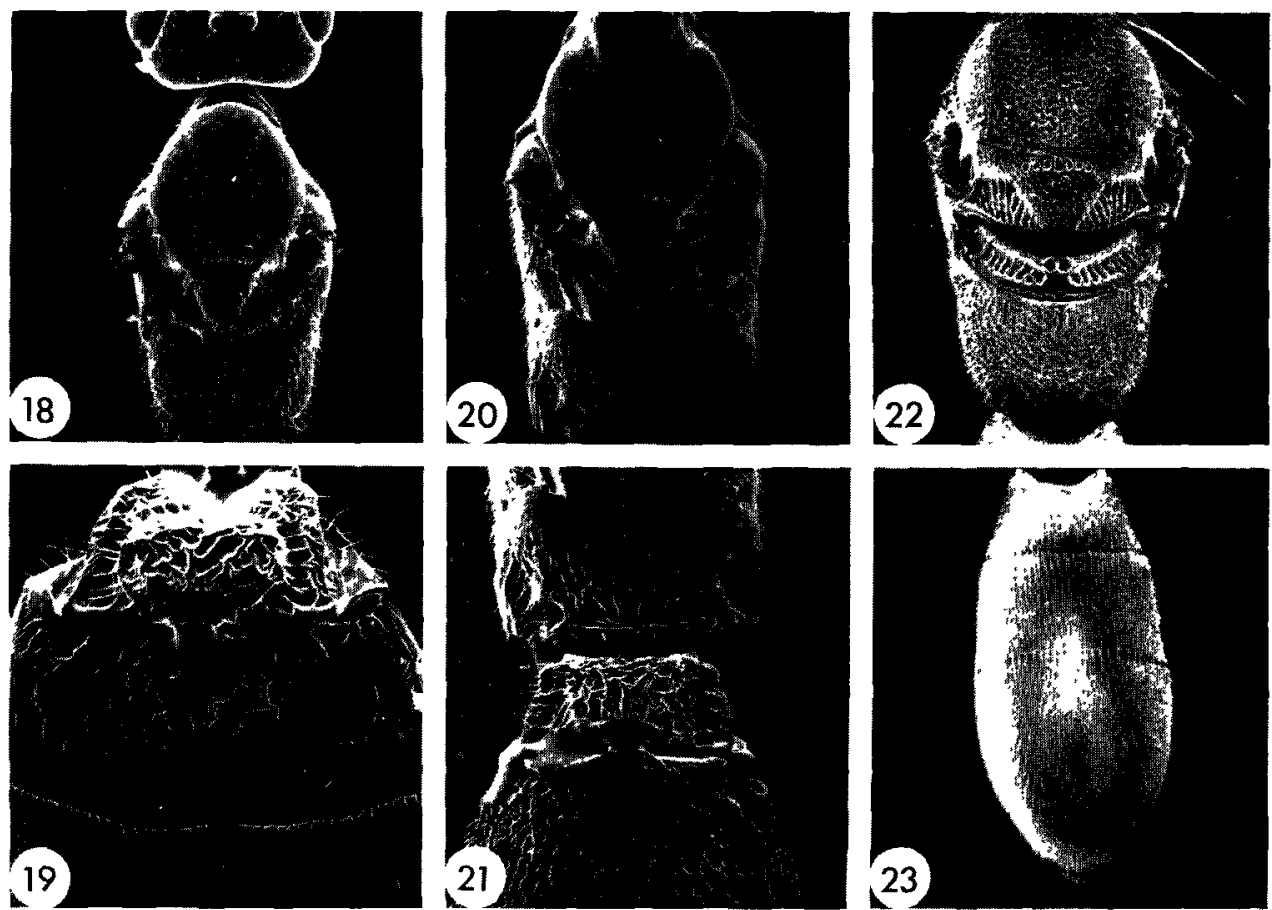

Figs 18-23. 18-19, Bracon testaceorufatus - 18, mesosoma, dorsal; 19, metasoma, basal tergites; 20-21, Tropobracon antennatus. 20, mesosoma dorsal, 21, metasoma, basal tergites, 22-23, Phanerotoma saussuret 22, mesosoma, dorsal; 23, metasoma, dorsal 



Figs 24-32. 24, Rhaconotus sp head, anterior (h=hypoclypeal depression), 25, Rhaconotus scirpophagae head, dorsal, 26, $R$. carnatus head, dorsal; 27-29, $R$ scirpophagae. 27, mesosoma, dorsal, 28, mesosoma, lateral; 29, metasoma, basal tergites; 30-32, $R$ carinatus. 30, mesosoma, dorsal; 31, mesosoma, lateral; 32, metasoma, basal tergites. 

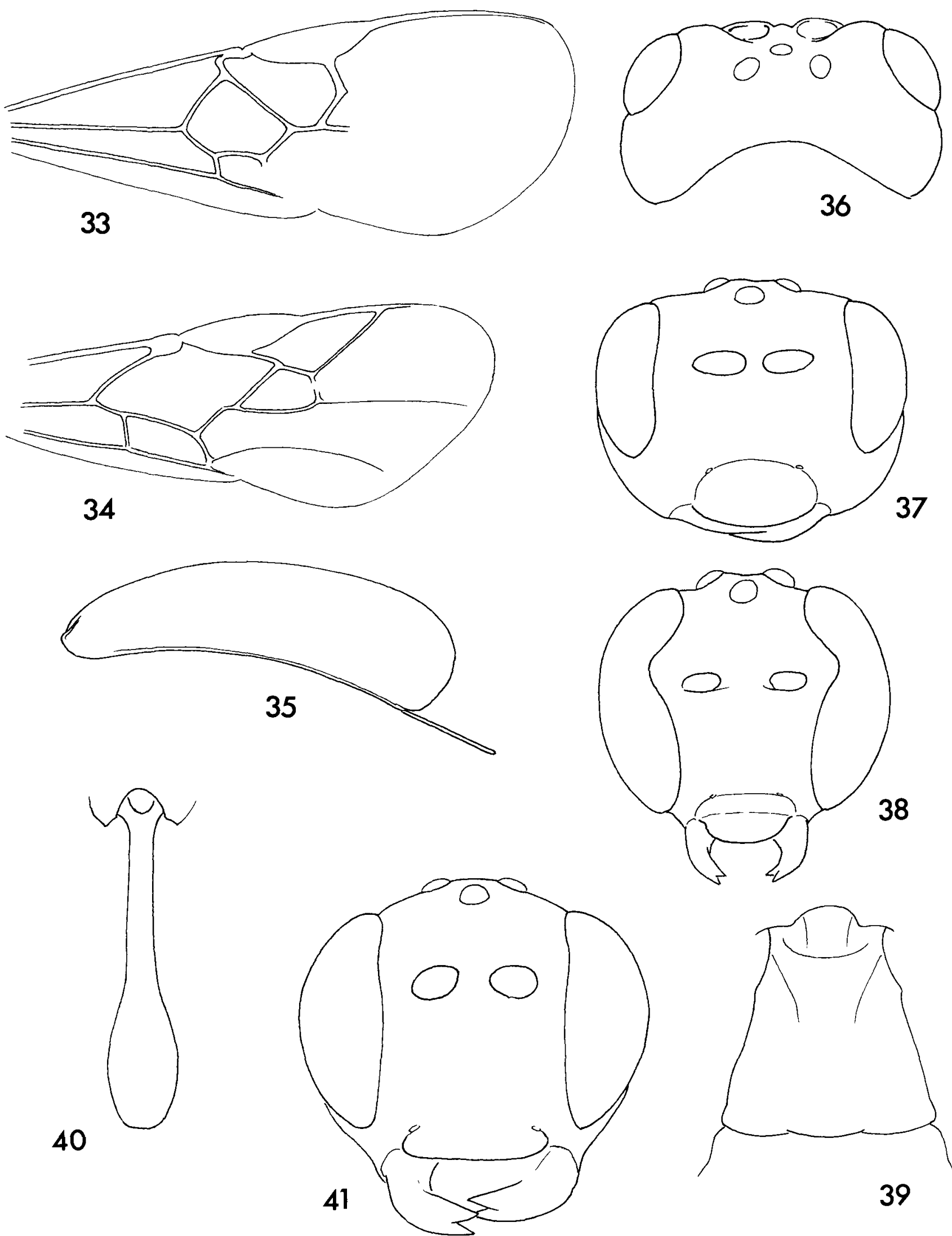

38

Figs 33-41. 33, Cotesia ruficrus fore wing; 34-37, Chelonus maudae: 34, fore wing; 35, metasoma, lateral; 36, head, dorsal; 37, head, anterior; 38-39, Itoplectis naranyae: 38, head, anterior; 39, metasoma, tergite I, 40-4I, Venturia jordanae: 40, metasoma, tergite I, 4I, head, anterior. 

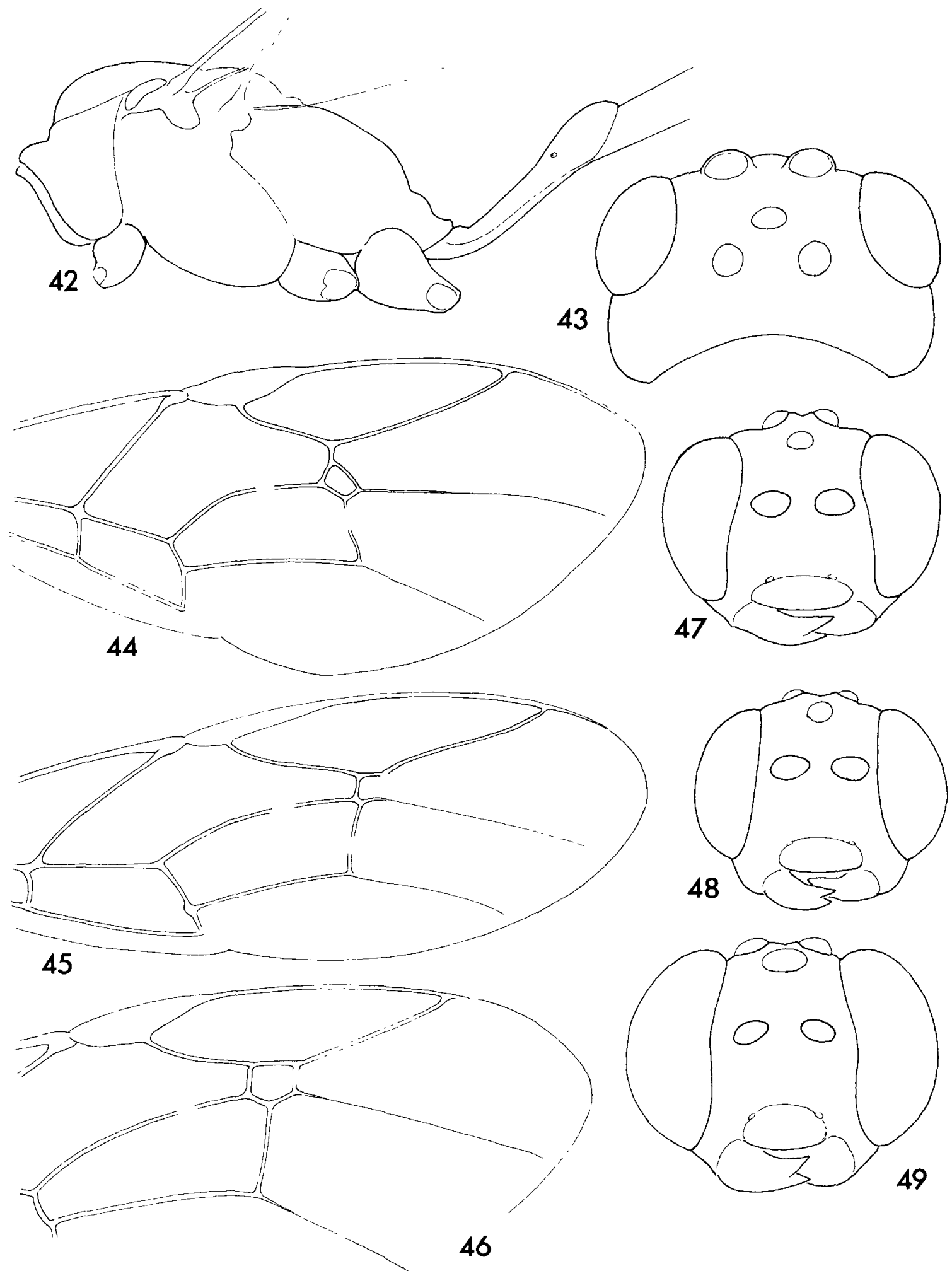

Figs 42-49. 42-44, Venturia jordanae - 42, mesosoma, lateral 43, head, dorsal; 44, fore wing; 45, Amauromorpha sp. A fore wing; 46, Vadonina inmbipennis fore wing, 47. Pristomeris bullis $(j)$ head, anterior; 48, P. africator $(j)$ head, anterior; 49, $P$. caris $(j)$ head, anterior. 

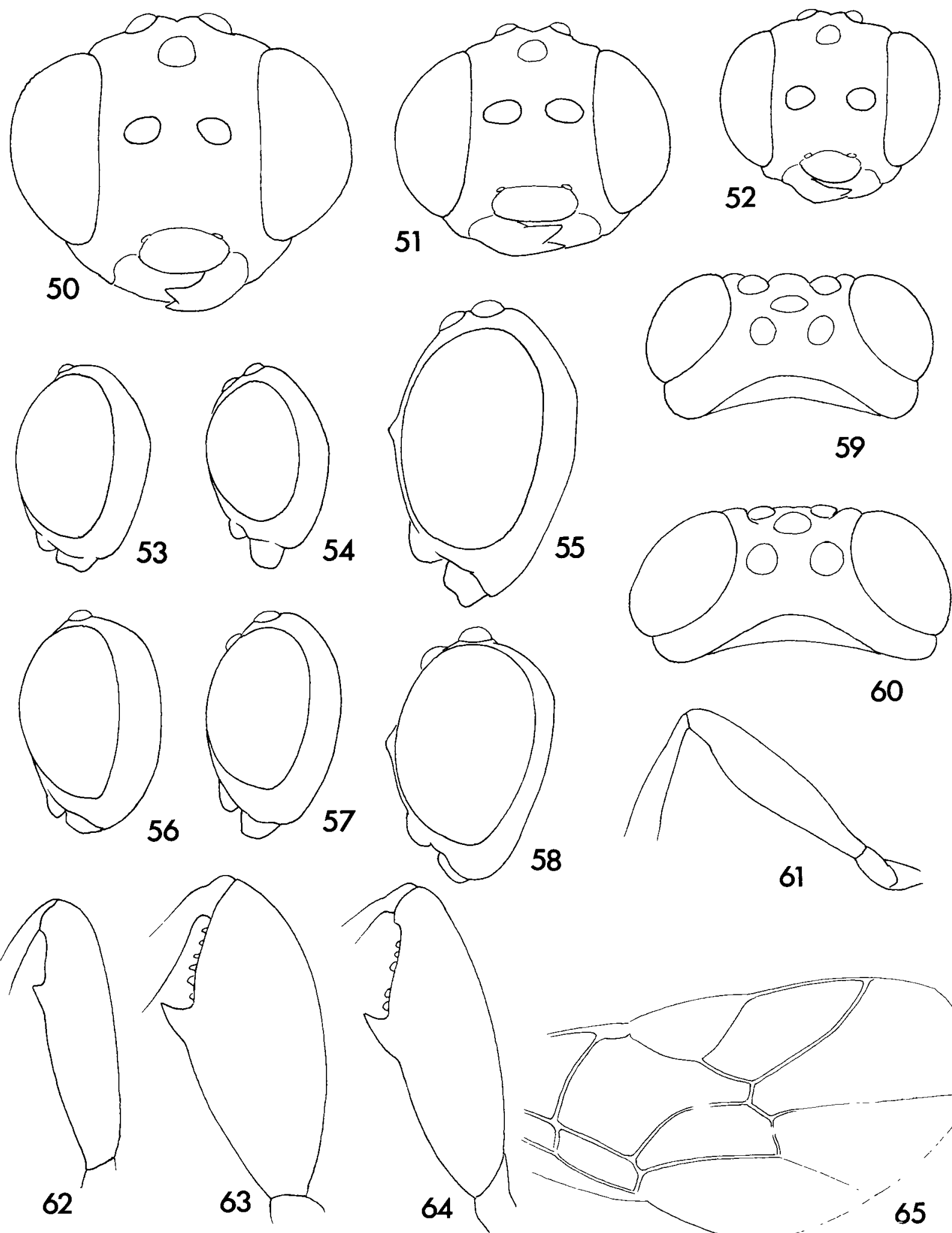

58
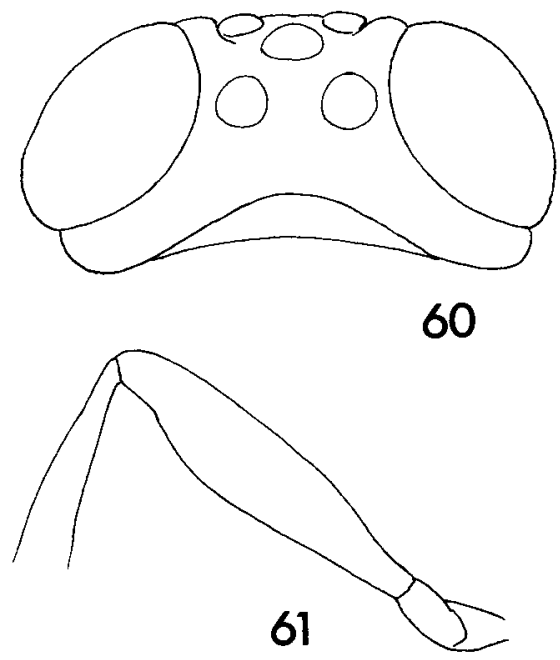

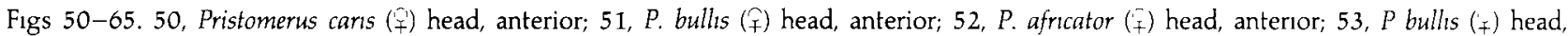
lateral; 54, $P$. africator ( $)$ head, lateral, 55, $P$. caris $(\hat{q})$ head, lateral; 56, $P$. bullis $(\hat{\zeta})$ head, lateral; $57, P$ africator $(\hat{j})$ head, lateral, $58, P$

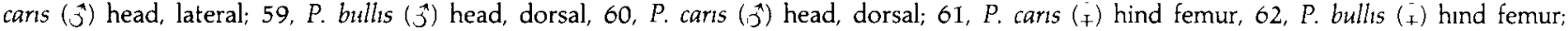

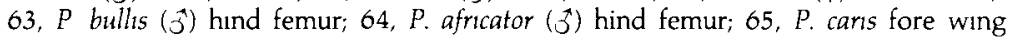



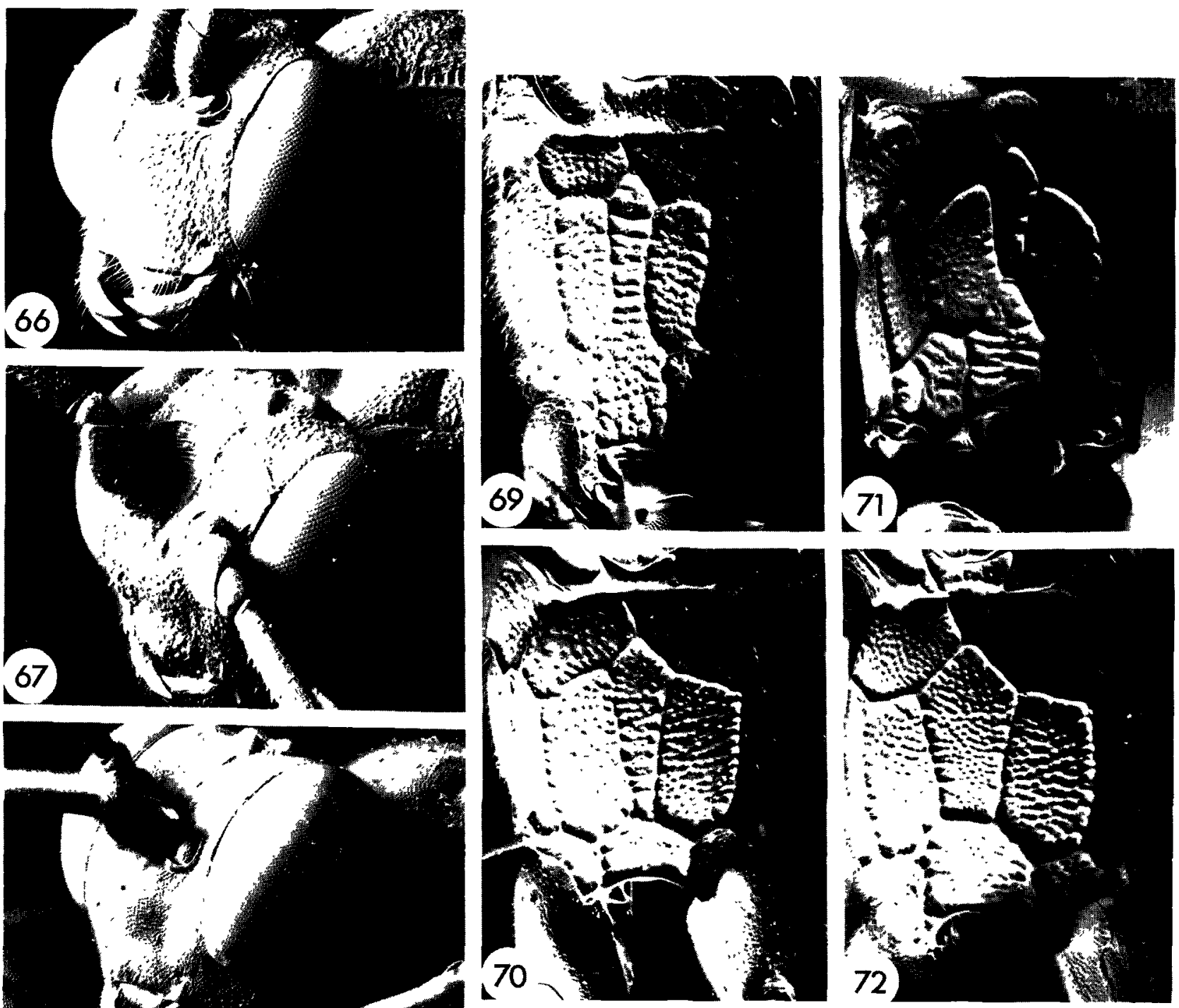

68

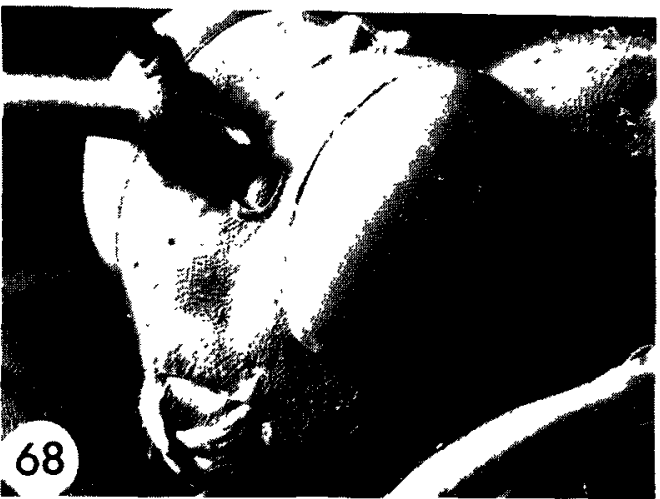

72

Figs 66-72 66, Ventura jordanae head; 67, Vadonina? ntmbipennis head; 68, Amauromorpha sp A head; 69, Venturia 10rdanae propodeum; 70, Pristomerus bullis propodeum; 71, $P$ caris propodeum; 72, P. africator propodeum. 

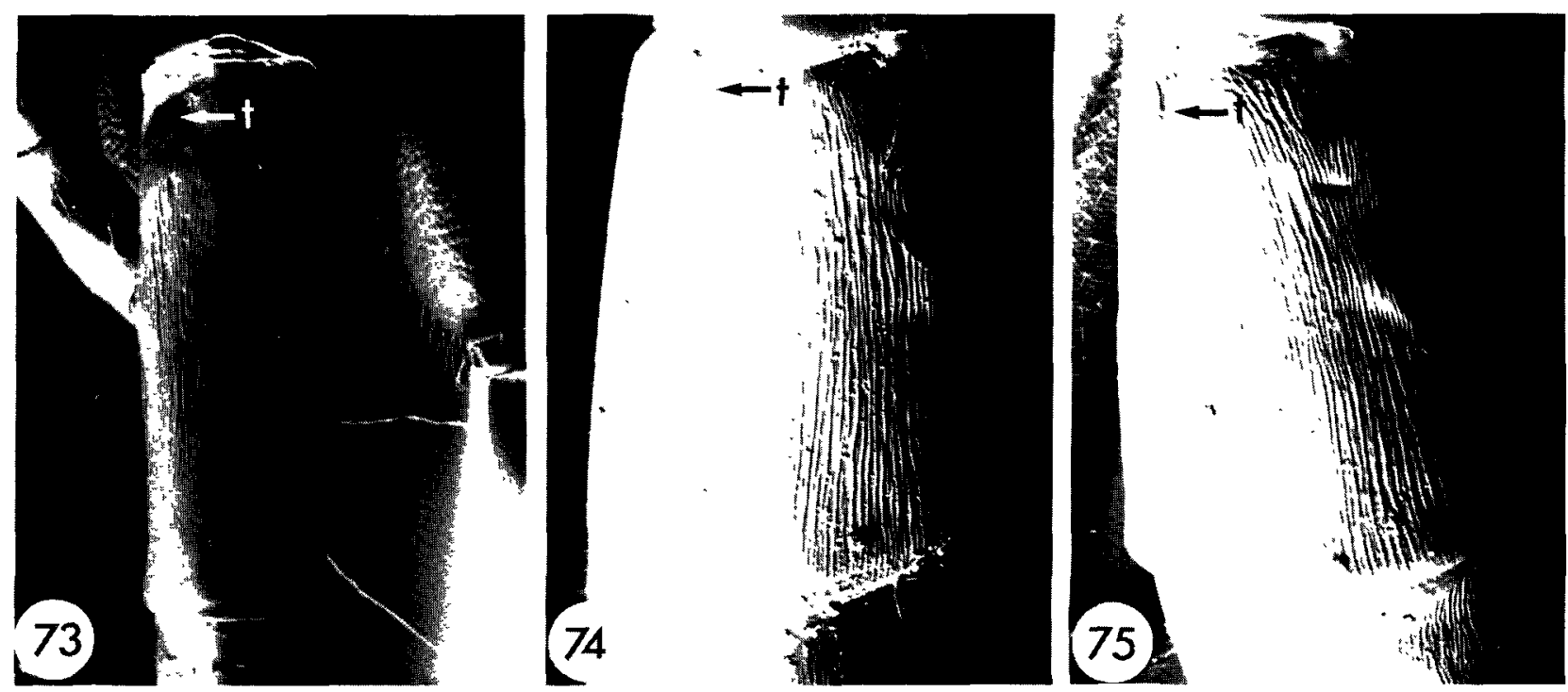

Figs 73-75. 73, Pristomerus carls tergite $2 ; 74, P$. bulls tergite $2 ; 75, P$ africator tergite 2
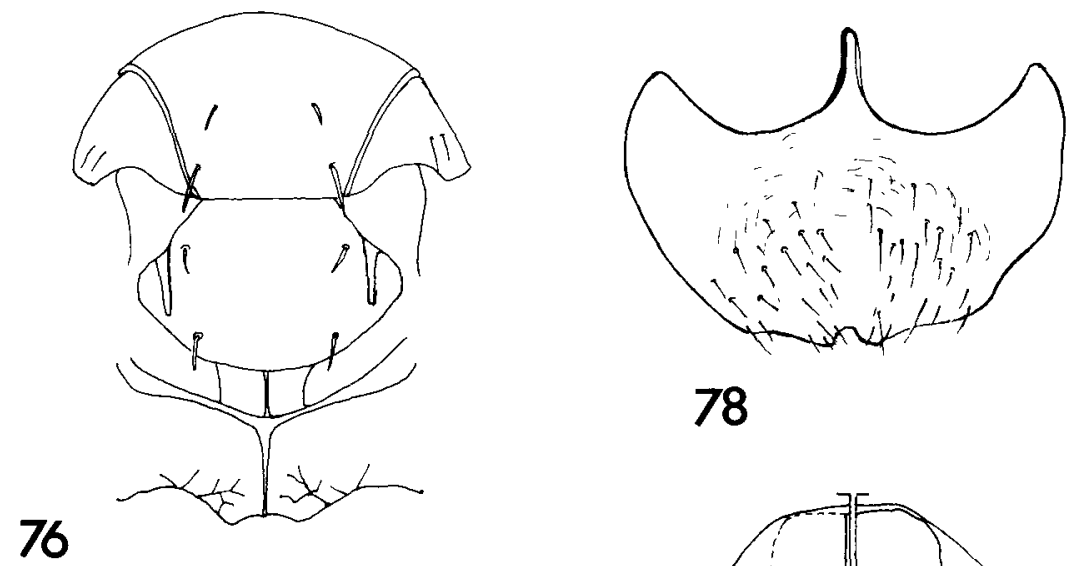

78
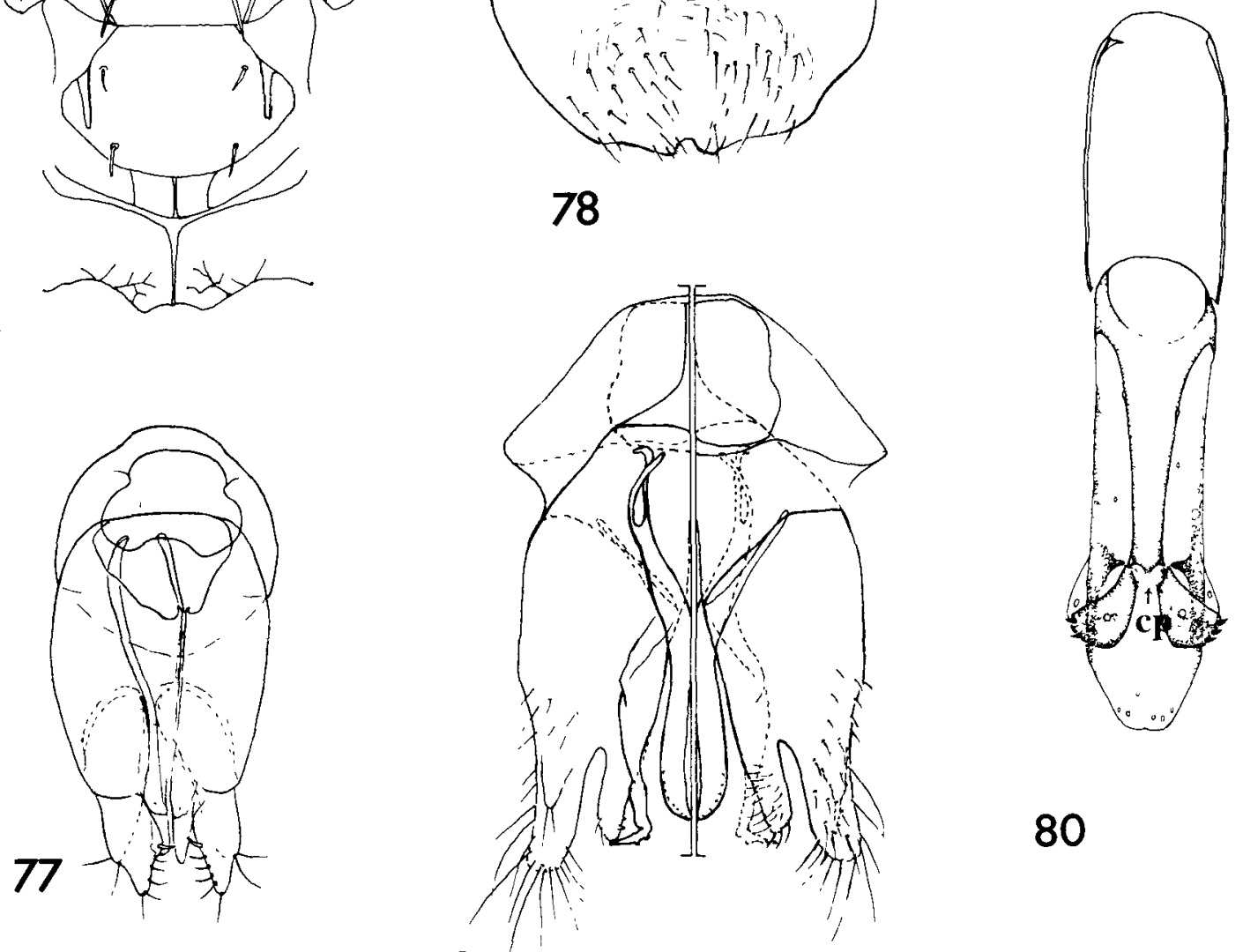

79

Figs 76-80. 76, Tetrastichomyıa sp A mesosoma, dorsal; 77, Aphanogmus fintensts (j) genitalia (from Dessart, 1971), 78-79, Goniozus indicus (3): 78, subgenital plate; 79, genitalia, 80, Telenomus bim $(\hat{j})$ genitalıa. 


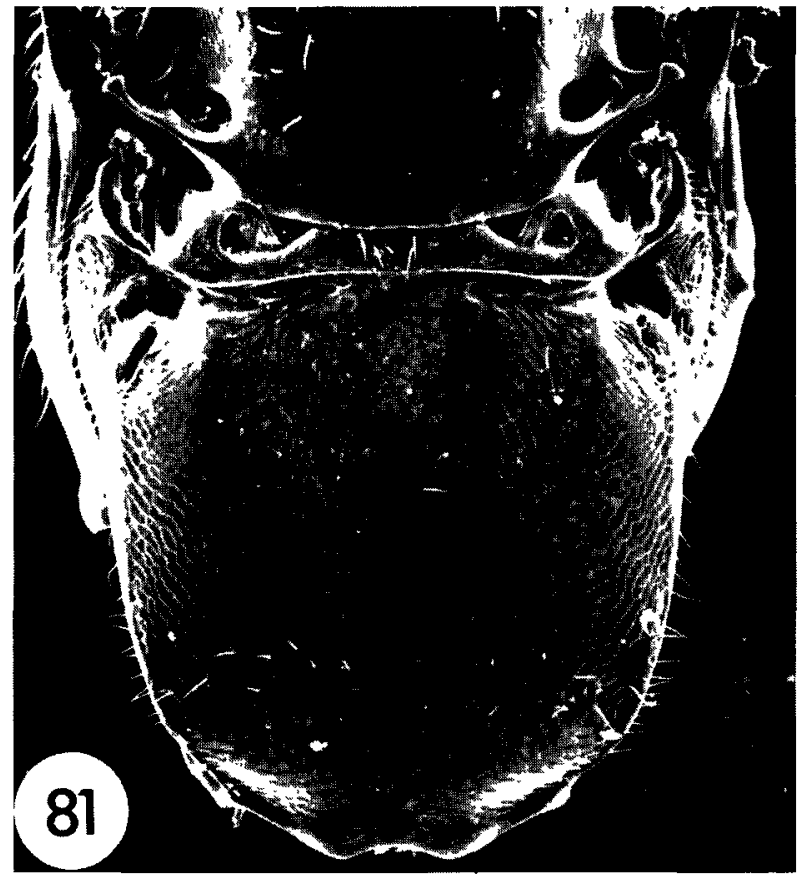

Fig 81. Gonozus indicus propodeum, dorsal.

a smooth, triangular area tapering antero-posteriorly on the dorsal surface (fig. 81) Genitalia and sub genital plate of male as in figs 78,79

Alternative hosts. Pyralidae Chlo infuscatellis Snellen, C. partellus (Swinhoe), C. sacchariphagus (Bojer), C. suppressalis (Walker) (laboratory host), C. zacconus Bleszynskı, Chilo sp., Conesta ignefusalis (Hampson), Corcyra cephalonica (Stainton) (laboratory host), Diatraea centrella Moeschler, $D$ lineolata (Walker), Eldana saccharma (Walker), Emmalocera depressella (Swinhoe), Scirpophaga excerptals (Walker), S. incertulas (Walker), S nivella (F.), S. occidentella (Walker), Sctrpophaga sp. (see Biology, below).

Distribution All of sub-Saharan Africa, Mauritius and Madagascar. Asıa. Bangladesh, India, Pakıstan

Biology Like most Gonozus, a gregarious larval ectoparasitord, usually attackıng concealed larvae of Lepıdoptera. Oviposition follows temporary anaesthesia, and is into the dorsum of the larva The biology of $G$. indicus (as $G$ procerae) under laboratory conditions is given in detail by Ly (1976), Ndoye (1980) and Coquard (1987)

Gordh \& Moczar (1990) list Cruptophlebta carpophaga (Walsingham) and Cnaphalocrocis medinalis (Guenée) among the hosts of G. indicus We have examined Gonozus specimens reared from $C$. medinalis and from Cruptophlebia sp., from India They are not $G$ indicus, and these species seem unlikely to be (natural) hosts of G. tndicus.

Remarks Type material of G. mdicus Ashmead, G. indicus Muesebeck, G. procerae Risbec and G. natalensis Gordh was compared for this study Several hundred specimens of $G$. indicus from Africa and Asla were also examined No important differences were found, and these species are therefore here regarded as conspecific

The syntype series of $G$ procerae consisted originally of $7 F$ and $2 ;$ mounted on three microscope slides One female, on a slide with a partially dissected (by Risbec) male was clearly marked 'type' in Risbec's writing. This female has since been remounted on a card-point and is now labelled 'lectotype'. The following are now labelled as paralectotypes the first slide previously containing the lectotype, now containing a remaining male (partially dissected); a second slide containing the genitalia of this male (used for Risbec's original figure) and two females; a third slide containing the genitalia (which are aberrant and asymmetrical) of the second male of the series, and five specimens $(1 \hat{j}, 4 \hat{q})$ mounted on two card squares. In the original description, nine females and two males were mentioned The remaining two females, if they ever existed, have not been located. Also in the original description, the hosts were mentioned as 'Adelpherupa sp. et Salurea sp. (Pyralıdae)' The type series is labelled (by Risbec) 'ex Proceras africana' (=Chilo zacconius) No specimen was located in Risbec's collection with the names of the former genera, neither has any specimen ever been recorded from these hosts since the description. It seems highly probable that the names of these hosts were published in error.

A distinct species of Gonozus (Parasierola-group) is also widespread on lepidopterous cereal stem borers in Africa (Girlıng, 1977; Conlong \& Graham, 1988), which Gordh (1986) suggested might be the same as $G$. natalensis. This species is known to us so far only in association with maize.

Gonozus indicus has been the subject of several studies in relation to biological control of the stem borer $E$. saccharina in South Africa (Conlong et al., 1988; Graham \& Conlong, 1988, as G. natalensis). It is also a well-known parasitoid of the millet stem borer C. ignefusalis in the West African Sahel (Ndoye, 1980; as G. procerae). Goniozus indicus was introduced into Madagascar (where it may well have already been present) from Senegal in 1973, for the attempted biological control of $M$. separatella (Appert, 1975), and into Réunion in 1972 (Betbeder-Matibet, 1977). Gontozus indicus was imported into Trinidad for the biological control of sugarcane borers in 1960 . It successfully attacked two Diatraea species (see hosts, above), but it is not known whether it became established (Bennett, 1965).

\section{BRACONIDAE: Braconinae}

\section{Bracon testaceorufatus Granger \\ (figs 18, 19)}

Bracon testaceorufatus Granger, 1949.71 Holotype 7 , MADAGASCAR. Bekıly, (reg. sud de l'ile) vil 1936 (A. Seyrig) (MNHN) [examined]. Bracon testaceorufatus Brenière et al., 1962; Appert, 1967, 1973, Anon, 1989.

Braconidae [sp. indet.] Tran, 1977.

Bracon quadratmotatus Granger- Bordat, 1979 (misidentificatıon).

Diagnosts. Length $2.0-4.5 \mathrm{~mm}$, excluding antennae and ovipositor sheaths. Deep orange-brown, with the following dark brown-black. antennae, stemmaticum, most of the wing venation, ovipositor sheaths, fifth tarsal segments; mesoscutum centrally, the sides varying from entirely without dark pigmentation to deeply pigmented; propodeum, first metasomal tergum, second metasomal tergum centrally and third and fourth terga broadly pigmented. Antenna (female) with 26-36 segments Head transverse, head and mesoscutum smooth and shining, notauli smooth, shallowly impressed. Propodeum coarsely sculptured, especially distally. Sculpture of frrst metasomal tergum, and second tergum centrally, strongly rugose (fig. 19). Male as female but habitus somewhat narrower, antennae with a few more segments and first metasomal tergum often paler than in female. 
Alternative hosts. Pyraildae: Chilo diffusilmeus (J. de Joannis), C. zacconius, Chilo sp., Scirpophaga sp.

Distribution. Cameroon, Côte d'Ivorre, Ghana, Kenya, Madagascar, Mali, Mauritania, Mozambique, Nigerıa, Senegal, Tanzanıa, Uganda.

Biology. A gregarious larval ectoparasitold (6-14 individuals per host) with an average fecundity of $25 \mathrm{eggs}$ and a developmental time of 12 days. The larvae pupate within the nce stem, a few centimeters below the host's remains. Emergent adults leave the stem via the aperture made by the host larva. In Madagascar, at least part of the population undergoes larval diapause whereas the remainder is active throughout the year (Bianchi et al, 1991).

Remarks. In areas of Madagascar where this species was abundant it had no important role in regulating populations of $M$. separatella (Appert, 1967). During September and October 1989 B testaceorufatus was the most abundant parasitoid of $M$. separatella at Lac Alaotra, Madagascar (Anon., 1989) In Bouaké, Côte d'Ivorre, $B$. testaceorufatus was abundant on irrigated rice from May to June (Tran, 1977).

\section{Mesobraconoides psolopterus (Wilkinson)}

Mesobracon psolopterus Wilkunson, 1931: 394. Holotype ₹, SIERRA LEONE N Jala, ex coffee branch borer, em. 4 xil. 30 (E. Hargreaves) $(\mathrm{BMNH})$ [examined].

Mesobraconotdes psolopterus (Wilkınson): Sarhan \& Quicke, 1990 221

Diagnosis. Length $6.0-70 \mathrm{~mm}$. Antennae with about 55-60 flagellomeres, the median flagellomeres considerably longer than wide. Wings largely infumate, pterostigma yellow to orange, hind leg and metasoma largely orange to red.

Alternative hosts. Coleoptera Scolytıdae Xyleborus sp.

Distribution Nigeria, Sierra Leone.

Biology Unknown, probably an ectoparasitoid, attacking the final larval instar of the host (Sarhan \& Quicke, 1990).

Remarks The inclusion of this species is based on two published records of its attacking $M$. separatella in Sierra Leone (Sarhan \& Quicke, 1990) No material reared from M. separatella was examined during the present study.

\section{Tropobracon antennatus (Granger) (figs 20, 21)}

Habrobracon trangularts Szépligetı, 1911 405. Holotype + [Kenya] Mombasa (Hildebrandt) (HMB) lexamined].

Bracon antennatus Granger, 1949. 61. Replacement name for $H$. trangularis Szépligetı.

Tropobracon antemnatus (Granger) Etienne, 1987

Habrobracon sp.. Risbec, 1950.

Mesobracon sp.: Ingram, 1958.

Shirakia sp.: Appert, 1973, Badawy, 1967, Jordan, 1966.

Diagnosis. Length 2.5-65 mm (excluding antennae and ovipositor sheaths). Body entirely deep orange except the following dark areas. antennae, stemmaticum, claws and base of fifth tarsal segment, ovipositor. Occasionally the triangle on $\mathrm{T} 2$ bordered with dark pigmentation which extends to a median longitudinal stripe the length of the metasoma. Pterostigma uniformly pale brown. Antenna with 50-65 segments Sculpture of mesosoma as in figure 20, mesoscutum with evident reticulate sculpture. Dorsally visible part of ovipositor + sheaths about half the length of the metasoma Male as female except for genitalic characters and the following. habitus narrower than in female and triangle on T2 usually complete at its apex.

Alternative hosts. Diptera: ?Diopsis curva Bertolinı (Rısbec, 1956a) Noctuidae: Sesamia cretica Lederer, Sesamia sp.; Pyralidae Chlo zacconius, Chilo sp.; Coniesta tgnefusalıs; Scirpophaga sp.

Distributıon. Cameroon, Côte d'Ivoire, Kenya, Madagascar, Malawı, Mali, Mozambique, Niger, Nigerıa, Senegal, Sierra Leone, Somalıa, South Africa, Sudan, Togo, Uganda.

Biology. A gregarıous larval parasitoid, T. antennatus is also known from stem borers of millet and wheat According to Jordan (1966) this species makes a small cocoon inside the stem on which its host has been feeding, usually an inch or so above the host's remains. The host record from Diptera. Diopsidae requires confirmation.

Remarks Three other closely related species of Tropobracon are known to attack lepidopterous cereal stem borers in the Palaeotropics. Tropobracon antennatus can be most easily distinguished from these by the reticulate sculpture of the mesoscutum (fig. 20). A key to Tropobracon spp. is provided by van Achterberg (1993).

In Madagascar, this species is uncommon on $M$ separatella or other rice borers ( $\mathrm{P}$ Bousses, pers comm.)

\section{BRACONIDAE: Cheloninae}

\section{Chelonus maudae Huddleston sp. $n$. (figs 34-37)}

Description. Length $6-8 \mathrm{~mm}$. Female antenna with $28-29$ segments, filiform; basal flagellar segment at least $3 \times$ as long as broad, each succeeding segment slightly shorter. Head strongly rounded behind eyes (fig. 36) Eye slightly longer than temple in dorsal view Frons strongly depressed behind antennae, coarsely rugose, sometımes reticulate. Vertex coarsely reticulate-rugose at sides but with strong transverse rugae medially, behind ocelli Ocellı moderately large, $\mathrm{OO}=2.0-2.5 \mathrm{OD}$, almost on line. Eyes large, not protuberant Face at least twice as broad as high (fig. 37), only weakly convex, coarsely rugose with a reticulate element laterally. Clypeus distinctly narrower than face, moderately convex, densely, finely punctate; apical border produced but truncate medially Malar space marked by a band of fine rugulose sculpture. Mandibles large, moderately twisted. Thorax (mesosoma) rather depressed, in lateral view almost twice as long as high. Pronotum projecting distinctly in front of mesonotum, reticulate laterally, transversely striate dorsally. Notaulı deeply impressed, foveolate Mesonotum generally coarsely reticulate-rugose except for small, smooth punctate areas laterally. Precoxal suture indistingushable from the coarsely reticulate-rugose sculpture of the mesopleuron. Propodeum coarsely reticulate-rugose, divided by a strong transverse medial carina that is raised laterally into blunt dentate flanges. Carapace elongate, oval in dorsal view, ventral opening not reaching apex; posteroventrally strongly impressed medially Ovipositor long (at least half as long as carapace), narrow Hind coxa rugose dorsally, densely finely punctate ventrally

Colour black, but antennae brown; fore leg yellow except coxa and trochanter brown, mid leg brown except apex of femur, base of tibia and sometimes tarsus yellow, hind leg brown but always with a medial pale band on tıbia, and often also base of tarsus yellow. Carapace with lateral pale areas anteriorly. Sternites and 
ovipositor sheaths brown, sometimes pale Male same as female except antennae 31-segmented, carapace more parallel-sided in dorsal view with smaller pale areas anterolaterally and no strong medial impression posteroventrally.

Material examined. Holotype 7 SENEGAL: Djıbelor, 15. ×.1979 (J Etienne) [ex larva Maliarpha separatella on rice] (MNHN). Paratypes 33,29 , same data as holotype (BMNH, MNHN). 19 Senegal, Kagnout, 13.x1.1969 (B Vercambre) lex M. separatella] (MNHN).

Alternative hosts. None known

Distribution. Senegal

Biology. A solitary egg-larval endoparasitord. Quartey (1975) referred to a 'genus near Chelonus ?sp' attacking $M$. separatella in Ghana which had a $7-29 \%$ parasitization rate. It is not unlikely that he was observing $C$. maudae, although we have not been able to recover the original material on which these observations were based.

Remarks Chelonus maudae is most closely related to $C$. capensis Cameron; the carapace of $C$. capensts, however, has a much shorter ventral opening and the posteroventral impressed part is therefore much longer. The temples of $C$. capensis are less strongly rounded and the sculpture on most parts of the body is less well developed

\section{Phanerotoma saussurei Kohl}

$$
\text { (figs 22, 23) }
$$

Phanerotoma saussure Kohl, 1906: 125. Holotype $\subsetneq$ (mistakenly given as $\hat{j}$ in original description), MADAGASCAR. Tamatave (NMW) [examined].

Phanerotoma major Brues, 1926. 266. Holotype F, [KENYA] Britısh East Africa: Masai Reserve (BMNH) [examined] syn. n.

Phanerotoma major: Jordan, 1966; Agyen-Sampong, 1980; AgyenSampong \& Fannah, 1987

Phanerotoma saussurel: Appert, 1967

Phanerotoma sp: Etıenne, 1987

Diagnosts. Length $6.0-8.0 \mathrm{~mm}$. Entirely orange/brown; antennae, stemmaticum and occasionally the posterior metasoma brown, but otherwise without any distinct brown or black markings. Pterostigma uniformly orange. Body dorsoventrally flattened. Metasoma distinctly longer than mesosoma. Propodeum coarsely retıculate, without distinct carnae. Face with striate sculpture, tentonal pits deep. Reared always in association with rice stem borers.

Alternative hosts Pyralıdae: Chilo zacconius, ?Sarpophaga sp.

Distribution Kenya, Madagascar, Malı, Senegal, Sierra Leone, Tanzanıa.

Biology A solitary egg-larval endoparasitoid, with a fecundity of 90 to 130 eggs. The life cycle is synchronized with that of its host, and death of the host occurs at the host's prepupal stage, with the emergence of the final instar parasitoid larva. Pupation occurs in the vicinity of the host remains within a bottle-shaped cocoon, about $14 \mathrm{~mm}$ long. Adult emergence occurs 12-14 days later (Buanchi et al., 1991) In Madagascar this species is active throughout the year at Marovoay, from the end of December on the plateau but enters diapause at Lac Alaotra between July and October (Bianchi et al., 1991).

Remarks. In the BMNH collection there are three specimens of $P$. saussure labelled 'S.E. Asta, L. Caresche CIE A1745'. These specimens were part of a donation by Dr Caresche in 1971, which
Included many specimens from Cambodia and Vietnam, but it is doubtful whether the Phanerotoma specimens were collected from either of those countries. Dr Caresche was himself involved with classical biological control of stem borers in Madagascar in the 1960 s, a more probable origin for these specimens. According to Appert (1967) P. saussuret was ineffective in controlling $M$ separatella in Madagascar.

\section{BRACONIDAE: Doryctinae}

\author{
Rhaconotus carinatus Polaszek sp. $n$. \\ (figs 17, 26, 30-32)
}

Rhaconotus niger (Szépligeti). Appert, 1967, 1973; Brenuère et al., 1962; Blanchi et al., 1991 (misidentifications).

Rhaconotus nr sudanensis Wilkinson: Jordan, 1966.

Rhaconotus sp.. Etienne, 1987.

Rhaconotus nr sciron Nixon: Alam, 1992.

Diagnosis. Length $3.5-6.0 \mathrm{~mm}$ Apex of fifth metasomal tergum simple, not dentate or sinuate. $\mathrm{T} 2+\mathrm{T} 3$ of the metasoma with a single division (fig. 32). Fore wing with pterostigma dark (fig. 17), each antenna with about 30 segments. Mesoscutum with a median longitudinal carina posteriorly (fig. 30).

Description. Female with ground colour dark red/brown with the following dark brown/black an ill-defined inverted triangle on the vertex, most of the mesoscutum, propodeum, lateral areas of metasomal terga and ovipositor. Head matt with fine reticulate sculpture, moderately setose, the setae directed posteriorly. Antenna with 28-33 segments. Mesoscutum as in figure 30, with reticulate sculpture except the median part posteriorly with an Irregular, longitudinal carma having several short lateral branches. Only the notaul and edges of the mesoscutum with setae, the mid and side lobes of the mesoscutum asetose centrally. Propodeum as in figure 30, sculpture largely finely reticulate dorsally, with a central longitudinal carına and two shorter carınae laterally. Posteriorly sculpture becoming more rugose. Fore wing (fig. 17) with the pterostigma very distinctly infuscate. Metasoma with the fused $\mathrm{T} 2+\mathrm{T} 3$ divided by a single groove; the longitudinal striae on $\mathrm{T} 2$ continuing posteriorly across this groove into the anterior part of T3, without being interrupted by an irregular transverse carina (as in $R$. sudanensis Wilkinson). Dorsally visible part of ovipositor about $2 / 3$ the length of the metasoma. Male largely as for female except for genitalia characters; habitus somewhat narrower.

Alternative hosts. Pyralidae: Chilo zaccontus.

Distribution. Cameroon, Ghana, Madagascar, Nigeria, Senegal, Sierra Leone, Tanzania, Togo

Biology. A gregarious larval ectoparasitoid (6-27 individuals per host), with a fecundity of 10 to 30 eggs. Developmental time is about 20 days, and adult females show a preference for attacking fourth or fifth instar larval hosts. The cocoons are white and can be distinguished from those of $B$. testaceorufatus by being more closely aggregated and by the smoother texture of the silk. At Lac Alaotra this species undergoes a winter diapause to reappear during October (Bianchi et al., 1991)

Material examined. Holotype $q$. Cameroon, near Santchou, Plaine de Mbo $250 \mathrm{~km}$ North Douala, i.1991, (G. Bianchi) $/ 8$ (BMNH). Paratypes $\left(2 \delta^{\circ} 28\right.$ \%) same data as holotype (BMNH, MNHN, RMNH). 
Remarks. Type material of those African and Asian Rhaconotus described by Granger, Nixon and Szépligeti which come at all close to $R$. carmatus has been examined.

\section{Rhaconotus scirpophagae Wilkinson} (figs 16, 25, 27-29)

Rhaconotus scirpophagae Wilkınson, 1927. 34. Lectotype (here designated): INDIA: Pusa, Bihar 18.11.1914 'ex Scirpophaga aurflua in sugar stem' (BMNH) [examined].

Rhaconotus sp nr oryzae Jordan, 1966.

Rhaconotus sp. Mathez, 1972

Rhaconotus sp nr scirpophagae Alam, 1992.

Diagnosis Length $4.0-7.0 \mathrm{~mm}$ Head and mesosoma densely harry, the hairs on the mesosoma arranged as in figure 27. Hind margin of pronotum usually obscured by a ndge, mesosoma narrow, its sculpture and setation as in figure $27 \mathrm{~T} 2+\mathrm{T} 3$ of metasoma divided by a simple slightly curved groove. Antenna of female with more than 40 segments. Pterostigma uniformly pale, colouration and venation of fore wing as in figure 16

Alternative hosts Noctuidae: Busseola fusca, Pyralidae: Chlo partellus, Chilo sp., Sarpophaga ?excerptals, S. moella. Scirpophaga sp.

Distribution. Africa: Côte d'Ivoire, Ghana, Kenya, Nigeria, Senegal, Sierra Leone, Tanzanıa (Wilkinson, 1927). Asıa. India, Java, Pakistan.

Biology. A gregarious larval ectoparasitoid.

Remarks. The holotype of Rhaconotus caudatus (Szépliget1) differs in very few respects from $R$ scirpophagae, and may well be conspecific. We have refrained from synonymizing the two species pending a thorough taxonomic revision of Rhaconotus from the Old World tropics.

In addition to the two Rhaconotus species treated here, at least five other species are recorded as attackng other stem borer species in the Old World tropics These are the following: $R$ caulicola Muesebeck, $R$. oryzae Wilkınson, $R$. roslinensis Lal, $R$. schoenobivorus (Rohwer) and R. signipennis (Walker).

Rhaconotus scirpophagae was described from Scirpophaga auriflua on sugarcane. Scirpophaga aurflua is a junior synonym of $S$. nivella, a rice stem borer. According to Lewvanich (1981), records of this species from sugarcane are probably misidentifications of $S$. excerptals.

\section{BRACONIDAE: Microgastrinae}

\section{Cotesia ruficrus (Haliday)} (fig. 33)

Microgaster ruficrus Haliday, 1834: 253 [Whereabouts of syntypes unknown]. For full synonymy see Nixon, 1974.

Diagnosis. Length $20-25 \mathrm{~mm}$ Ocellı in a high triangle. Antenna as long as body, the two preapical segments each about $17 \times$ longer than wide. Mesoscutum shining, coarsely punctate Scutellum deeply and strongly punctate. Phragma of scutellum concealed by postscutellum. Hind coxae dull, rugose, Inner spur of hind tibia not reaching beyond middle of basitarsus. Tergite $2+3$ highly polished distally to basal field, setae restricted almost to a single row in the middle, frequently double at the sides. Hypopygium short, roundly truncate at apex as seen in profile (Nixon, 1974). Colour: legs bright red/yellow, hind femur dark distally. Metasomal tergite $2+3$ with yellow markings.

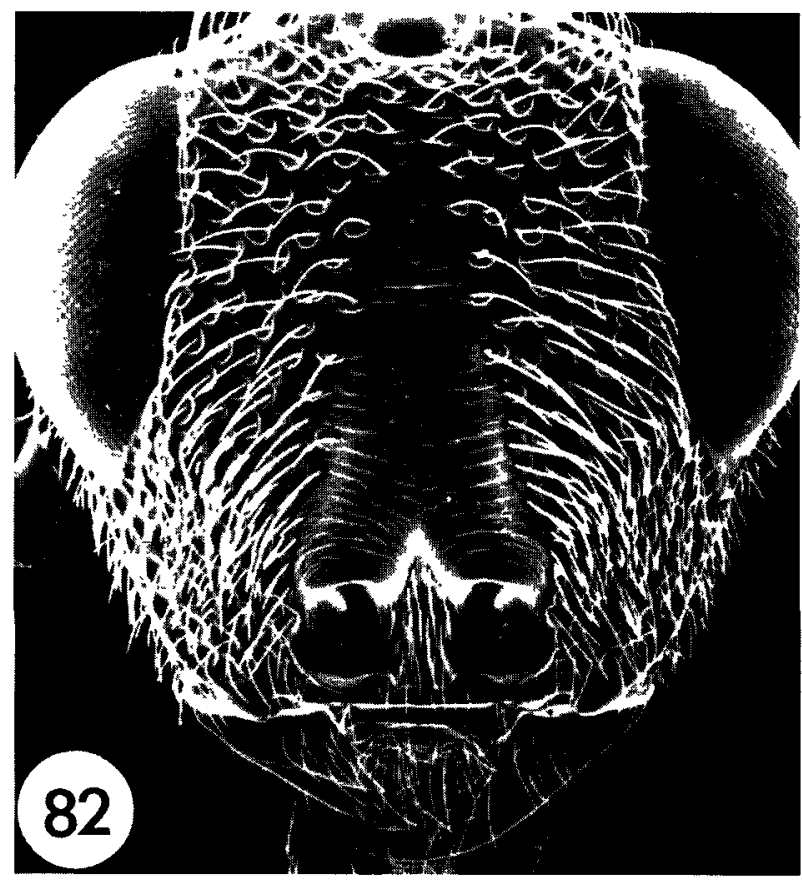

Fig 82. Psilochalcis soudanensis head, anterior

Alternative hosts. An extremely polyphagous species. Additional African cereal stem borer hosts not mentioned by $N_{1 x}$ (1974) are the following: Noctudae: Sesamia nonagrioides Lefebvre, Pyralidae: Chilo zacconus

Distribution. Cosmopolitan in the Palaeotropics and Palaearctic. Biology. A gregarıous endoparasitord.

Remarks Reared from $M$ separatella at Kotiessou, Côte d'Ivorre, by Dr A Pollet (I $\hat{j}, 2_{f}^{\prime}$, CIRAD, examıned)

\section{CERAPHRONIDAE}

\section{Aphanogmus fijiensis (Ferrière) (figs 1, 12, 77)}

Callıceras fijiensis Ferrıère, 1933: 106. Holotype FIJI: Taveunı, xı 1931 (R.W. Paine) ex Apanteles trathabae (BMNH) [examined] Aphanogmus filensts (Ferrière). Dessart, 1971: 98.

Diagnosis. Length $0.9-2.2 \mathrm{~mm}$ Wing venation as in figure 12 Mesopleuron almost entirely smooth (fig 1), genitalia as in figure 77.

Hosts Aphanogmus finensts attacks a wide range of hymenopterous primary parasitoids, mostly Braconidae It is especially commonly recorded from cocoons of Apanteles spp., Cotesta spp. and Dolichogendea spp (Apanteles sensu lato) and is often reared from braconid primary parasitoids of cereal stem borers in Africa

Distribution Pantropical, accidentally introduced into many parts of its range (Dessart, 1971).

Biology A gregarious secondary endoparasitord. 
Remarks. Aphanogmus finensis has never, to our knowledge, been recorded in association with $M$ separatella, but it seems likely that it eventually will be, and is therefore included here

\section{CHALCIDIDAE}

\section{Psilochalcis soudanensis (Steffan) \\ (figs $4,14,82$ )}

Hyperchalcudia soudanensis Steffan, 1951.67

Invreta soudanensis (Steffan) Bouček, 198853.

Psilochalas soudanensts (Steffan). Narendran, 1989. 184

Diagnosis. Length 30-70 mm Head, hind femur and wing venation as in figures 4,14 and 82 .

Alternative hosts Noctuidae. Busseola fusca (Fuller), Pyralıdae. Chlo aurcalius Dudgeon, C. mfiscatellus, $C$ partellus, $C$ aaconus, Conesta ignefusalis, Eldana saccharina

Distribution Africa Cameroon, Ghana, Kenya, Nigerıa, Malı, Niger, Senegal, Sudan, Uganda. Asıa. India, Pakıstan

Biology. Solitary larval-pupal endoparasitoid

Remarks Despite the widespread occurrence of $P$. soudanensis, we have not seen any specimens from Madagascar A single male of a very closely related (and probably undescribed) species, almost certainly reared from $M$. separatella at Tanandava, Madagascar, has been examined by $Y$ Jongema (pers. comm) It seems wise to wait until further, reliably reared, material becomes available before treating this species. Appert (1973) referred to the proposed introduction of $P$ sondanensis into Madagascar and the Comoros aganst Chlo sp. and Maliarpha separatella. Presumably this introduction never took place

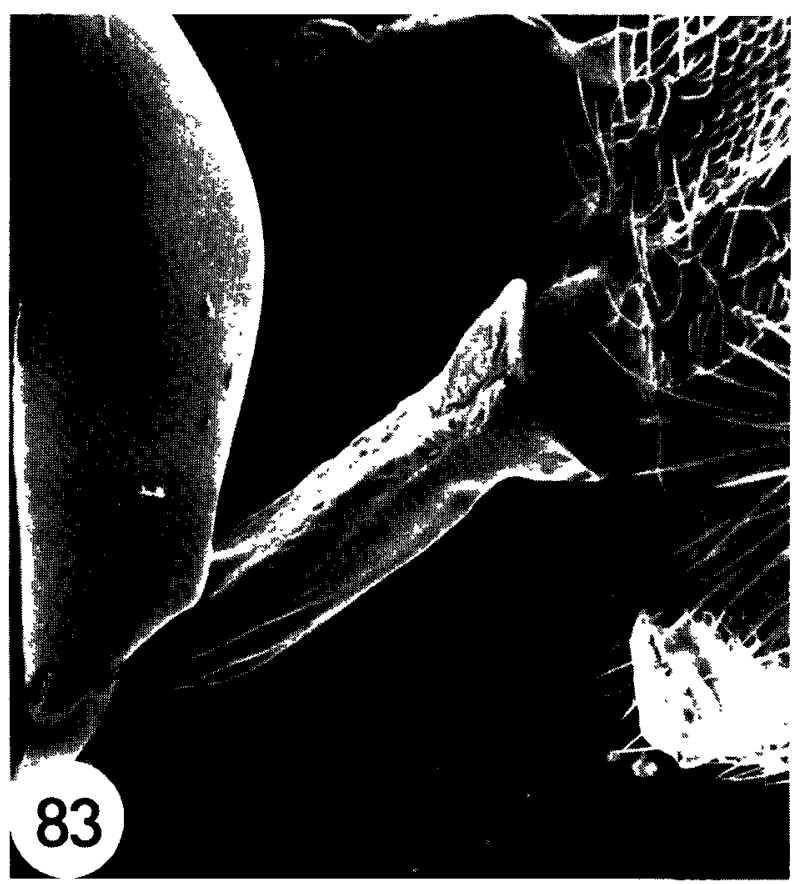

\section{ELASMIDAE}

Elasmus sp. A

Duagnosis. Length $190 \mathrm{~mm}$ Hind coxa enlarged and flattened as in figure 3. Wings uniformly infuscate (brown) head and body with a contrasting pattern of orange and black areas, the following black: most of head, pronotum centrally, central mesoscutum proximally, axillae, postscutellum and propodeum centrally, hind coxae and most of metasoma dorsally.

Alternative hosts. None known.

Distribution Senegal.

Brology. Not known.

Material exammed. 3\% SENEGAL: Casamance iv-v.90 (G Bianchi) ex M. separatella (specimen labelled as follows: Elasmus sp A Bull. Ent Res 1994, Polaszek et al.) (BMNH)

Remarks Elasmus spp. are known both as primary parasitords, mostly of Lepidoptera, but also as hyperparasitoids Elasmus zehntnen is a primary parasitoid of stem borers in Asia. The species treated here is known from only three specimens reared from $M$. separatella, and it is not known whether they were primary or secondary parasitoids

\section{EULOPHIDAE}

Tetrastichomyia sp. A

(fig. 76)

Diagnosts. Length $170 \mathrm{~mm}$ Wing venation reduced with the stigmal vein straight (as in figs 11 \& 13) Tarsi 4-segmented, the hind coxa not expanded and flattened. Dorsum of mesosoma as in figure 76 , dorsellum of mesosoma divided by a median longitudinal ridge.

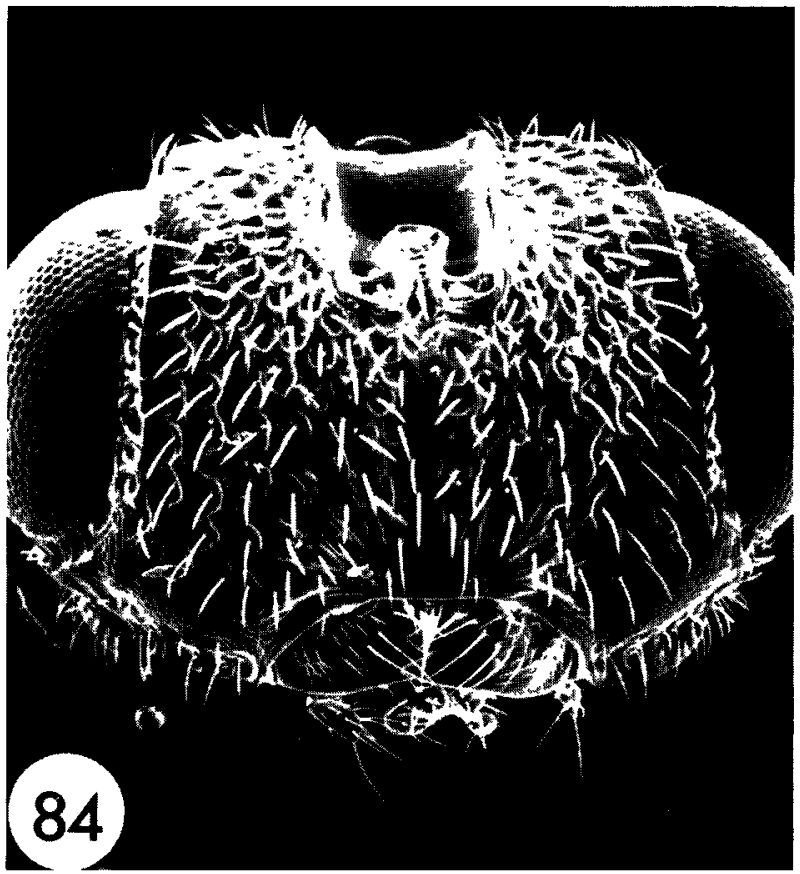

Figs 83-84. Eurytoma oryzivora. 83, petiole lateral; 84, head, anterior. 
Alternative hosts. None known.

Distribution. Uganda.

Biology. Presumably a primary parasitoid

Material examined. 1q UGANDA: Toro (Tetrastichomyı sp. A Bull Ent Res 1994, Polaszek et al.) (BMNH).

Remarks. This species differs from Tetrastichomyia clisiocampae, a widespread species (Italy and USA), which is also known to attack cereal stem borers (Graham, 1991; J. LaSalle, pers. comm.).

\section{EUPELMIDAE}

\section{Macroneura sp. A}

Diagnosis (q). Length $3.50 \mathrm{~mm}$. Mesopleuron convex as in figure 5 , wings reduced. Pronotal dorsum with two prominent tufts of thick dark setae. Brown/black with blue/purple irridescence.

Alternative hosts. None known.

Distribution. Senegal.

Biology. Not known.

Material examined. 27 SENEGAL. Casamance IV-v.90 (G. Blanchi) ex Malarpha separatella (Macroneura sp. A Bull. Ent Res 1994, Polaszek et al.) (BMNH).

Remarks. This species is included here on the basis of two females reared from Malarpha separatella in Senegal.

\section{EURYTOMIDAE}

\section{Eurytoma oryzivora Delvare}

(figs $6,7,83,84$ )

Eurytoma sp.. Jordan, 1966; Agyen-Sampong, 1980; AgyenSampong \& Fannah, 1987; Etienne, 1987.

Eurytoma oryzivora Delvare, 1988: 130. Holotype q, CAMEROON. Yagoua, 1.1955 (Descamps) 'ex borer du Riz' (MNHN) [examined].

Diagnosis. Length $3.2-3.6 \mathrm{~mm}$ almost entirely black, with some areas reddish-brown. Metasoma petiolate (fig 83), petiole longer than wide. Mesopleuron with a distinct subpleural area, defined anteriorly by an epicnemial carina (fig. 7). Clypeus without a deep medial depression; face with foveolate/striate sculpture (fig. 84)

Alternative hosts Chilo sp.

Distribution. Cameroon, Senegal, Sierra Leone, Tanzania.

Btology. Assumed to be a primary parasitoid.

Remarks. The only other Eurytoma species commonly reared from cereal stem borers in Africa is the polyphagous hyperparasitoid $E$. braconidis Ferrière, which can be distinguished from E. oryzivora by the diagnosis given above, particularly by the lack of an elongate petiole and presence of a clypeal depression. Eurytoma braconidis has never, to our knowledge, been reared in association with $M$. separatella.

\section{ICHNEUMONIDAE: Campopleginae}

\section{Venturia jordanae Fitton sp. $n$.} (figs $40-44,66,69$ )

Scenocharops sp.: Jordan, 1966 [misidentification]. Cassarina [stc] sp.: Njokah \& Okhoba, 1985 [misspelling of Casinaria; misidentification]

Venturia crassicaput (Morley). Agyen-Sampong \& Fannah, 1987 [misidentification].

Diagnosts. Length $7.0-10.0 \mathrm{~mm}$ Slender, with the metasoma laterally compressed. Colour as described below. Characteristic campoplegine combination of confluent face and clypeus, black in colour, with coarse granulate sculpture and clothed with conspicuous silver hairs.

A closely related species of Venturia attacks Sesamia spp. bornng in rice (Jordan, 1966). It can be distinguished from $V$. jordanae by its slightly less slender proportions and, in the female, by its much longer ovipositor, which is more than 2.7 times as long as the hind tibia. The visible part of the ovipositor, the length of which equals the ovipositor sheaths, is more than twice as long as the hind tibia.

Description. Fore wing length $4.3-5.7 \mathrm{~mm}$. Head comparatively buccate, in dorsal view (fig. 43) gena about 0.9 times as long as eye. Mesosoma elongate, profile as in figure 42. Propodeal carinae as in fig 69. Mesosoma, including entire upper lateral area of pronotum and metapleuron, coarsely and closely punctate, with coarse granulate sculpture between the punctures. Fore wing with cu-a meeting $\mathrm{Cu}$ at the point of divergence of $\mathrm{M}$ and $\mathrm{Cu}$ (fig. 44). Metasoma elongate; segment $\mathrm{I}$ in profile as in figure 42; tergite $2,2.3-2.5$ times as long as wide posteriorly Ovipositor about 1.6 (the visible portion, which equals the ovipositor sheaths, about 1.0) times as long as hind tibia, with the tip slightly upcurved.

Colour: manly black and dark brown, with underside of antenna, mouthparts, tegula, fore and mid legs, hind trochantelli, and part or all of metasomal tergites 3-7 reddish or yellowish.

Alternative hosts. Jordan's data (1966) suggest that the species is restricted to $M$ separatella.

Distribution. Côte d'Ivoire, Kenya, Sierra Leone.

Biology. A solitary koinobiont endoparasitoid of the larva, killing the host in its pupal chamber or sometimes before the pupal chamber has been made. In the first case the adult $V$. jordan emerges through the 'window' prepared by the larval lepidopteran for the escape of the adult moth. In the latter case $V$ iordant has to make its own emergence hole (Jordan, 1966). In Sierra Leone the first adults emerge in November, rising to peak numbers in February and then declining unt1l August (Jordan, 1966).

Material examined Holotype $\nmid$, Sierra Leone: Rokupr, 1964-65, reared from $M$. separatella in rice (Jordan) (BMNH, London).

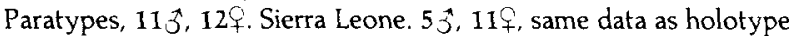
(BMNH, London). Sierra Leone: 23, 19, Rokupr, 1979-80 ex Maliarpha sp. on rice (WARDA) (BMNH, London). Ivory Coast 13. Man, iv-v.90, ex M. separatella (Branchi) (BMNH). Kenya: 23. Ahero, 22+23.ix.71, ex M. separatella in rice (Greathead) (KPCRS); 13 . Ahero Irrigation Scheme, near Kisumu, $350 \mathrm{~km} \mathrm{~W}$ of Narrobi, 1.1991 (Branchi) (BMNH)

Remarks. Of the described African species of Venturia this species and the related parasitoid of Sesamia come closest to $V$ crassicaput (Morley), of which the lectotype has been examined 


\section{ICHNEUMONIDAE: Cremastinae}

\section{Pristomerus africator Aubert \& Shaumar \\ (figs $48,52,54,57,64,72,75$ )}

Pristomerus sp.: Jordan, 1966.

Pristomerus pallidus africator Aubert \& Shaumar, 1978. 18. Holotype 3.. IVORY COAST: Bouaké, 28.i.1977 [P Cochereau] (Aubert collection) [not examined].

Pristomerus africator. Horstmann, 1990. 16

Diagnosts. Length $6.5-8.5 \mathrm{~mm}$. Colour as in $P$. bulls sp. $\mathrm{n}$. brownish-yellow overall, with face paler and antenna, wing veins and stigma, hind tarsi and a patch on metasoma tergite 2 darker. The two species can be separated as shown in the key.

Alternative hosts. ?Chilo on nce. Two specimens reared in Senegal may be $P$. africator, but this requires further consideration in conjunction with a revision of Pristomerus in Africa.

Distribution. Côte d'Ivoire, ?Egypt, Senegal, Sierra Leone. The record from Egypt is doubtfully correct (Horstmann, 1990)

Biology. A solitary, koinobiont, larval endoparasitoid. Jordan (1966) reports the host being killed as a larva and two adult males emerging in May and June. Dates (months) associated with other adult specimens examined are February, March, April and December, but some of these may refer to rearing under laboratory conditions.

Remarks. The species of Pristomerus are in need of revision. There are six described Afrotropical species, but there are many more in collections. Of the three species attacking $M$. separatella, $P$. africator and $P$ bullss are superficially similar and may be related to $P$ cunctator Tosquinet (of which the lectotype has been examined), while $P$. cars sp. $\mathrm{n}$ clearly belongs to another species-group. As noted above, the identity of some material reared from nce and other stem borers is currently in doubt.

Pristomerus bullis Fitton sp. $n$. (figs 47, 51, 53, 56, 59, 62, 63, 70, 74)

Description. Length $6.3-8.1 \mathrm{~mm}$ Fore wing length $4.5-5.6 \mathrm{~mm}$ Clypeus wider and less convex than in $P$. africator and with face less strongly widened ventrally (figs 47,51 , compare figs 48,52 ). Malar space narrow, about 0.5 (slightly less in male) of basal width of mandible Female with mesoscutum strongly punctured, male with centre of mesoscutum with only a few strong punctures. Propodeum with area superomedia shaped as in figure 70 . Tergite 2 of metasoma 1.6-2.0 times as long as broad posteriorly and thyridia shaped as in figure 74 . Hind femur stout in male, with a well developed tooth ventrally (fig. 63), relatively slender in female and with a small tooth (fig 62). Ovipositor about 1.8 (the visible portion, which equals the ovipositor sheaths, about 1.2) times as long as hind tibia, with the apex sinuous

Colour: brownish-yellow overall, with face paler and antenna, wing veins and stigma, hind tarsi and a patch on metasoma tergite 2 darker.

Alternative hosts. None known

Distribution Tanzania.

Bıology. Probably a solitary, koinobiont, larval endoparasitoid like other cremastines.

Material exammed. Holotype $q$, Tanzania, Morogoro region, Mkindo, i.1991, reared from $M$. separatella in rice (B1anch1)

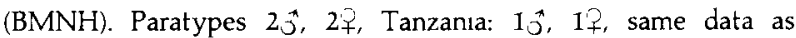
holotype (BMNH). Tanzania: 17, Zanzibar, 14.1.1986, reared from $M$ separatella (Feijen) (RMNH). Tanzania $1 \hat{j}$, Zanzibar, Ungoja, Bumbw[e]: ırr[igated] rice, 3.vi.1985 (Feijen) (RMNH).

Remarks. See remarks under $P$. africator.

Pristomerus caris Fitton sp. $n$.

(figs $49,50,55,58,60,61,65,71,73$ )

Description. Length $4.4-5.8 \mathrm{~mm}$. Fore wing length $3.4-4.6 \mathrm{~mm}$ Head with eyes relatively large, gena narrow (figs 55, 58, compare figs $53,54,56,57)$, face relatively narrow and strongly widened ventrally in male (fig. 49), male with enlarged ocelli, very close to eyes laterally (fig. 60). Mesoscutum strongly punctured. Propodeum with area superomedia shaped as in figure 71 . Tergite 2 of metasoma 17-2.1 times as long as broad posteriorly and thyridia shaped as in figure 73 . Hind femur relatively slender in female and without a distinct tooth ventrally (fig. 61) (tooth present in male) Ovipositor 2.2-25 (the visible portion, which equals the ovipositor sheaths, $1.5-18$ ) times as long as hind tibia; with the apex smuous

Colour brownish orange overall, with antennae and tergites 1 and 2 of metasoma blackish, and the head pale cream, except the face centrally brown, extending across the frons and back of the head as a broad black area. Male with the remainder of the metasoma infuscate and the female with the hind tarsi and ovipositor sheaths blackush.

Alternative hosts. None known.

Distribution. Madagascar.

Biology. Probably a solitary, koinobiont, larval endoparasitoid like other cremastines.

Material exammed. Holotype $f$, Madagascar- Lac Alaotra, Stn Cala, 12.11 1988, almost certanly reared from $M$. separatella (P. Bousses) $(\mathrm{BMNH})$. Paratypes, 23, 2q, same data as holotype (BMNH)

Remarks. See remarks under $P$. africator

\section{Temelucha sp. A}

Diagnosis. Length $4.3 \mathrm{~mm}$. A small species with a contrasting black-and-yellow colour pattern, the yellow areas varying to a lighter creamy colour and the black areas to a dark brown. The head, mesosoma and ventral surface of the metasoma are all extensively yellow.

Alternative hosts. None known.

Distribution. Madagascar.

Bılogy. Probably a solitary, koinobiont, larval endoparasitoid like other cremastınes.

Material examined. 1千 MADAGASCAR: Lac Alaotra, Station Cala 1502.88 ex M. separatella (Temelucha sp. A Bull. Ent. Res. 1994, Polaszek et al.) (BMNH).

Remarks. The single known specimen, a female, very probably represents an undescribed species. However, it seems prudent to wat until more material is available before giving it a name. 


\section{ICHNEUMONIDAE: Phygadeuontinae}

\author{
Amauromorpha sp. A \\ (figs 45,68 )
}

Diagnosis Length $8.5 \mathrm{~mm}$. The females, especially, of this and Vadonna inimbipennis Seyrig have a heavier build than most of the other ichneumonid species. Amauromorpha sp. A is mainly brownish orange in colour with the end of the metasoma black with a white band and with the head and antennae black, the latter with a white band in females.

Alternative hosts. None known.

Distribution. Togo (but see below)

Biology. Unknown, but possibly a solitary, idıobıont ectoparasitoıd. Material examined. 19 TOGO. 22.11 .80 (M. Tore) ex M. separatella CIE A12209 (Amauromorpha sp. A Bull. Ent. Res. 1994, Polaszek et al) $(\mathrm{BMNH})$.

Remarks. The single reared specimen, almost certainly represents an undescribed species. Two much larger female Amauromorpha in the $\mathrm{BMNH}$ collection-one from Malaw1 (not reared) and one from Nigeria (from a rice stem)-may be the same species. It seems prudent to wat until more material is available before deciding.

\section{Vadonina ?nimbipennis Seyrig (figs 46,67 )}

Vadonina nimbipennis Seyrig, 1952: 181. Holotype 7 , MADAGASCAR. Marsansitra (MNHN) [examined]

Gen. near Isotima sp.: Jordan, 1966.

Isotima nimbipennis: Townes \& Townes, 1973. 105.

Menaforia spp.: Agyen-Sampong \& Fannah, 1987 [misıdentification]

Diagnosts. Length $6.5-11 \mathrm{~mm}$. See note under Amauromorpha. Colour brownish with the mesosoma and anterior metasoma more reddish and the posterior metasoma, head and antennae darker, often almost black. The posterior tip of the metasoma and, in females, a band on the antennae, white.

Alternative hosts. Not known, see remarks below.

Distribution. Ghana, Kenya, Madagascar, Sierra Leone, Swazıland, Tanzania, Togo, Uganda.

Biology. Reported by Jordan (1966) to be a larval-pupal parasitord, but with no data supporting the contention that oviposition is into or onto the larva. Data attached to other specimens indicate they were reared from pupae Further investigation is obviously desirable in view of the wide geographic range and relative abundance of the species. Quartey (1975) recorded what is almost certainly this species from pupae of $M$. separatella in Ghana. At Lac Alaotra this species is found only rarely, but most frequently between September and December. Dates (months) associated with adults are January to May, August, November and December (but some of these may refer to laboratory rearings)

Remarks. Townes (1970) included V. nimbipennis within Isottma Isotima as recognized by Townes is a moderately large genus with an Afrotropical and Oriental distribution. However, $V$ nimbipennis and most (but not all) of the African species of this group lack the key character used by Townes to distinguish it (frons with a semi-circular carına above each antennal socket) As well as lackıng frontal carinae $V$. nimbipennis and related African forms have a distinctive habitus They are rather more 'robust' than Isotıma spp from the Oriental region Considering the state of the systematics of the group it seems best at present to regard them as separate genera.

Vadonina includes only one described species Study of the material avalable, much of it reared from lepidopterous cereal stem borers, reveals a range of variation in a number of characters. Species limits are not obvious and since material reared from $M$. separatella does not differ very significantly from the holotype of $V$. nimbipennts it is tentatively identified as that species until a revision of the genus is undertaken. Other material of Vadomna examined includes specimens from the following additional host and crops. Chllo partellus, sorghum and maize.

\section{ICHNEUMONIDAE: Pimplinae}

\section{Itoplectis naranyae (Ashmead) \\ (figs 38, 39)}

Nesopimpla naranyae Ashmead, 1906. 180 Holotype †. JAPAN: Sapporo ex Naranga diffusa (USNM) [not examined].

Itoplectis narangae Appert, 1973. 85.

Diagnosis. Length $70-10.5 \mathrm{~mm}$. The metasoma is rather broad (somewhat depressed) and mainly orange in colour. The head, the mesosoma usually, and the tip of the metasoma are black The legs are orange-yellow with conspicuous dark bands

Itoplectis naranyae is very close to, and may even be the same as, the Palaearctic species I. melanocephala (Gravenhorst) The latter differs mainly in having the legs (apart from the claws) entirely orange-yellow.

Hosts. Not yet recorded from $M$ separatella, but known from a very wide range of hosts, mainly Lepidoptera, but also Ichneumonidae (Hymenoptera) and Chrysomelidae (Coleoptera) (Gupta, 1987). Included here for the reasons given below.

Distribution. An eastern Asian species, introduced into several parts of the world to control various lepidopterous pests Stock of Japanese origin was introduced into Madagascar to control M. separatella in 1972 (Appert, 1973), but probably did not establish An attempt to introduce this species into Senegal aganst $M$ separatella (Vercambre, 1977b) also appears to have failed.

Biology. A solitary idiobıont endoparasitord usually of cocooned or weakly concealed pupae, but sometımes of pharate pupae or even pharate adults. Acting as a facultative pseudohyperparasitord when it attacks ichneumonids in their own cocoon or their host's cocoon or pupa.

Remarks We have seen no material of this species from the Afrotropical region. Even if established in the region it may not attack $M$. separatella and is included in our key only in case it does so.

\section{PTEROMALIDAE}

\section{Norbanus sp. A (figs 8, 9)}

Diagnosis Wing venation reduced, with the stigmal vein straight, as in figures 11, 13. Tarsi 5-segmented Mesopleuron divided, not in the form of a convex shield. Antenna of female with an elongate, 
pointed sensillum at the apex of the club (fig. 9). Mesosoma as in figure 8.

Alternative hosts. None known

Distribution Madagascar.

Biology Not known.

Material examined $1_{\mp}$ MADAGASCAR. Lac Alaotra, Station Cala. 1991 (P. Bousses) ex. M. separatella 91-34 (Norbanus sp A Bull. Ent. Res. 1994, Polaszek et al.) (BMNH).

Remarks. This species is known from a single female specimen reared from $M$ separatella from Madagascar. The genus Norbanus is in need of taxonomic revision Several records of species parasitizing lepidopterous cereal stem borers are known from Africa.

\section{SCELIONIDAE}

\section{Telenomus bini Polaszek \& Kimani \\ (figs 13, 80)}

Telenomus bin Polaszek \& Kımani, 1990: 62. Holotype Jै, MADAGASCAR: Lac Alaotra, Stn 'Cala', 2.111.1983 (P. Bousses) [ex $M$. separatella] 'LB7' (MNHN) [examined].

Telenomus applanatus (part) Bin \& Johnson, 1982. 234.

Telenomus sp.1, groupe lemoleae Nixon, Etienne, 1987.

Diagnosis. Minute black species, length less than $1 \mathrm{~mm}$. The genus is extremely large, and several closely related Telenomus spp. are associated with rice stem borers in Africa These can only be successfully identified using male genitalia characters (fig. 80). Detailed treatments of these species are avallable (Polaszek \& Kimani, 1990, Polaszek et al, 1993).

Alternative hosts. Pyralidae: ?Chilo sp.; Sarpophaga ?subumbrosa Meyrick.

Distribution. Côte d'lvoire, Ghana, Kenya, Madagascar, Malawı, Senegal, Tanzanıa.

Bılogy. Telenomus bini, like all Scelionidae, is an egg-parasitord. Records from hosts other than $M$ separatella are extremely rare, and all records are associated with rice. This species can be reared easily on Maliarpha in the laboratory, but it does not oviposit into eggs of Ephestia kuehntella Zeller or Corcyra cephalonica Stainton (both Pyralidae) (Brenière et al., 1962) At Lac Alaotra (Madagascar) its life cycle lasts 16 days during the warmest months (December, January), and it has a fecundity of about 26 eggs (Branchi et al., 1991)

Remarks. We have examıned many hundreds of specimens of $T$ bom from populations spanning its known distribution. Most previously published records of Telenomus spp. from $M$ separatella probably refer to T. bin

\section{TRICHOGRAMMATIDAE}

\section{Lathromeris ovicida (Risbec)}

(figs 10, 11)

Garouella ovicida Risbec, $1956 \mathrm{c} \cdot 818$. Lectotype $Q$ (here designated): [CAMEROON:] Garoua vir.1955 [(M] Descamps[]] 'ex w Lepid. $\mathrm{s} / \mathrm{rnz}^{\prime}$ (MNHN) [examined].

Lathromeris ovicida (Rısbec). Doutt \& Viggianı, 1968: 504; Viggiani, 1969: 205 (redescription).
Diagnosis. Minute species with wing venation as in figure $I 1$. Antennal club five-segmented, terminating in an elongate projection (fig. 10). Funicle absent, two ning segments present.

Alternative hosts. Noctuidae: Busseola fusca; Sesamia calamistis; Pyralidae: Chilo zacconiss; Sarpophaga subumbrosa.

Distributıon. Benin, Cameroon, Côte d'Ivoire, Ghana, Nigeria, Uganda.

Biology. A primary egg parasitoid, attacking several species of stem borers in a variety of habitats Commonly recorded from eggs of maize stem borers.

\section{Discussion}

Durıng the present survey over 20 species of Hymenoptera were found to parasitize Maliarpha separatella, a few as definite or probable hyperparasitoids. This study was carried out in conjunction with a broader survey of all parasitords of lepidopterous cereal stem borers in Africa, Madagascar and the associated islands (Polaszek, 1992). From the broad survey it was found that several species attacking $M$. separatella are polyphagous for cereal stem borers, or for a broader host range, and very few appear to show any degree of host specificity at the species level. Only Telenomus bimi, an egg parasitoid, appears to be strongly host specific. Telenomus bint is extremely common on $M$. separatella both in Africa and Madagascar, and has been reared from alternative (also rice inhabiting) stem borer species on only two occasions. Some of the other species have been reared on too few occasions to be certain of any degree of host specificity, e $g$ Chelonus maudae, but should be further investigated for biological control capabilities.

A strikıng feature of the survey for $M$. separatella parasitoids is the complete lack, so far, of any dipterous parasitoids. For other stem borer species, in Africa and elsewhere, Tachinidae in particular are commonly encountered attackıng stem borer larvae. However, for Africa and Madagascar there is only a single published record of a native tachinid species attackung a rice inhabiting stem borer larva (Actia sp. on Chilo zacconius, Sierra Leone, Jordan, 1966) Hence, an avalable niche may exist for an imported tachinid biological control agent.

Current studies on biological control of cereal stem borers in Africa are focusing on the Asian braconid Cotesta flavipes (Cameron) to control Chilo partellus, also an Asian species (Overhoit, 1993) Another Asian species, Cotesta chilonis (Matsumura), is invariably associated with Chilo sp. in rice. Its ability to develop successfully on $M$. separatella is worthy of investigation. The related, indigenous (African), Cotesia sesamtae (Cameron) is common on most stem borer species, but does not give adequate control. Cotesia sesamiae has not, to our knowledge, been recorded from $M$. separatella. A study of the reasons for this may shed light on the suitability of Cotesta spp. as potential biological control agents of $M$. separatella.

In summary, it would appear that despite the abundance and diversity of hymenopterous parasitoids of $M$. separatella, neither their individual nor collective impact is sufficient to control it in the areas where it is a recognized pest. This is certainly true of the common, widespread parasitoid species. More detailed studies on the less common species, or those with a restricted distribution, are likely to suggest agents which could be imported from one region into another. In particular, the biological control potential of Tachinidae and exotic Cotesta spp. merits investigation for $M$. separatella control.

Whatever initiatives develop in the future of biological control of $M$. separatella, it should now at least be possible to identify the 
parasitoids associated with this species, or species-complex. Identification of natural enemies should always be the first step in the development of any biological control programme, and should certainly be an early step in the development of integrated pest management programmes.

\section{Acknowledgements}

This project was largely financed by grants from the Directorate General for International Cooperation (DGIS) of the Netherlands Government, the Swiss Development Cooperation (SDC) and the Swiss Federal Institute of Technology (ETH) Zürich. The authors thank Prof. V. Delucchi (ETH) for essential support.

Identifications of parasitoids were made by the following individuals: C. van Achterberg, Nationaal Natuurhistorisch Museum, (formerly Rijksmuseum of Natural History), Leiden, The Netherlands (RMNH) (Braconidae: Braconinae); Y. Jongema, Wageningen Agricultural University, The Netherlands (WAU) (Chalcididae); J. LaSalle, International (formerly Commonwealth) Institute of Entomology, London, UK (IIE) (Eulophidae, Eupelmidae, Pteromalidae); A.K. Walker (IIE) (Braconidae: Microgastrinae). Other groups were identified by MGF (Ichneumonidae) TH (Braconidae: Cheloninae) and AP (remainder).

Field collection in Africa was facilitated by the cooperation of the following organizations: Centre National de Recherches Appliquées au Dévéloppement Rural (CENRADERU), Madagascar; Département des Cultures Vivrières de l'Institut des Savanes (DCV-IDESSA), Ivory Coast; Institut Sénégalais de Recherches Agricoles (ISRA), Senegal; International Institute of Tropical Agriculture (IITA), Nigeria; National Irrigation Board, Kenya; Plant Protection Division, Ministry of Agriculture \& Livestock Development, Tanzania; Sous-Direction de la Protection des Végétaux-Ministère de l'Agriculture (SDPV-MINAGRI), Cameroon.

Specimens were kindly made available by the following: N.D. Bafokuzara, Kawanda Perennial Crops Research Station, (KPCRS) Uganda; P. Bousses, Projet 'Protection intégrée en riziculture', Lac Alaotra, Madagascar; J. CasevitzWeulersse, Muséum National d'Histoire Naturelle, Paris, France $(\mathrm{MNHN}) ; \mathrm{G}$. Delvare, Centre de Coopération Internationale en Recherche Agronomique pour le Développement, Montpellier, France (CIRAD); P. Dessart, Institut Royal des Sciences Naturelles de Belgique (IRSNB); Brussels, Belgium; S. Diiba (ISRA); M. Fischer, Naturhistorisches Museum, Vienna (NMW); F. Koch, Zoological Museum of the Humboldt-University, Berlin, Germany (ZMB); K.V. Krombein, National Museum of Natural History, Smithsonian Institution (USNM), Washington, USA; G.L. Prinsloo, Plant Protection Research Institute (PPRI), Pretoria, South Africa; H. Robertson \& M.A. Cochrane, South African Museum, Cape Town, South Africa.

The following individuals/institutes helped greatly in the retrieval of literature: P. Cochereau, M.-C. Deboine, A. Diallo, J. Etienne and S. Quartey.

We also thank L. Ficken (BMNH) for taking the scanning electron micrographs and $\mathrm{M}$. Scoble for useful comments on the manuscript. D. Agosti (BMNH/University of Zürich, Switzerland) made valuable suggestions at the initial stages of this study.

\section{References}

Achterberg, C. van (1993) Revision of the genus Tropobracon Cameron (Hymenoptera: Braconidae). Zoologische Mededelingen 67, 49-62

Agyen-Sampong, M. (1977) Lutte contre les insectes nuisibles du riz au Ghana. Delibérations du Sémmaire WARDA/ADRAO, mars $197748-55$.

Agyen-Sampong, M. (1980) Parasites of rice pests of mangrove swamps of Northern Sierra Leone. WARDA/ADRAO Techntcal Newsletter 2, 1-3.

Agyen-Sampong, M. \& Fannah, S.J. (1987) Seasonality of the white rice borer Mallarpha separatella Rag. (Lepıdoptera. Pyralidae) in the mangrove swamp rice ecology of northwest Sierra Leone. WARDA/ADRAO Technical Newsletter 7, $4-7$.

Akinsola, E.A. (1984) Effects of rice stem-borer infestation on grain yield and yield components. Insect Science and its Application 5, 91-94.

Akinsola, E.A. \& Agyen-Sampong, M. (1984) The ecology, bionomics and control of rice stem-borers in West Africa. Insect Science and its Application 5, 69-77.

Alam, M.S. (1992) A survey of rice insect pests in Nigerıa Tropical Pest Management 38, 115-118.

Anon. (1970) Pest control in nce PANS (Pest Articles and News Summaries) 3, 1-270

Anon. (1975) Rapport annuel du Centre National de Recherches Appliquées au Développement Rural (Madagascar) (CENRADERU), 247

Anon. (1977) Special Research Project, Annual Report West African Rice Development Association (ADRAO/ WARDA) 3.

Anon. (1989) Protection integrée en riztculture au Lac Alaotra (Madagascar) Rapport d'activité Août 1988-Juillet 1989. République Démocratique de Madagascar et Confédération Suisse (DDA). Institut de Phytiatre, EPF, Zurich 1-170

Appert, J. (1967) Les insectes nuisibles aux cultures de Madagascar (notes techniques). Bulletın Agronomique 22, 1-177.

Appert, J. (1970) Maliarpha separatella (borer blanc du riz). Observations nouvelles et rappels des problemes entomologiques sur riz a Madagascar. L'Agronomie Tropicale 25, $329-367$.

Appert, J. (1971) Les lepidoptères foreurs des graminées a Madagascar, aux Comores et aux Mascareignes. L'Agronomie Tropicale 26, 500-508.

Appert, J. (1973) Entomofaune parasitare des foreurs des graminées à Madagascar Entomophaga 18,77-94

Appert, J. (1975) Exemples des méthodes d'élévage et de dissémination des parasites et prédateurs d'intérêt économique à Madagascar. Rapport du premer cours en formation à la lutte contre les ennemies des cultures et plus spéctalement la lutte contre le criquet pelérin et aux recherches sur cet acridien. $17 \mathrm{fev} .1976$ FAO Rome. 239-242.

Appert, J., Betbeder-Matibet, M. \& Ranaivosoa, H. (1969) Vingt années de lutte biologique à Madagascar. L'Agronomie Tropicale 24, 555-572

Ashmead, W.H. (1903) 2. Descriptions of three new parasitic Hymenoptera from India. Indian Museum Notes 6, 2-3.

Ashmead, W.H. (1906) Descriptions of new parasitic Hymenoptera from Japan. Proceedings of the US National Museum 30, 169-201.

Aubert, J.-F. \& Shaumar, N. (1978) Supplément aux Ichneumonides d'Egypte Bulletin de la Société Entomologique de Mulhouse avril-juin 1978, 13-20. 
Badawy, A. (1967) Dura stem borers and their parasites in the Sudan Bulletın de la Société Entomologique d'Egypte 51, 233-241

Baumgartner, J., Regev, U., Rahalivavololona, N., Graf, B., Zahner, P. \& Delucchi, V. (1990) Rice production in Madagascar- regression analysis with particular reference to pest control. Agriculture, Ecosystems and Environment 30 , $37-47$

Bennett, F.D. (1965) Tests with parasites of Asian gramınaceous moth borers on Diatraea and allied genera in Trinidad. Technical Bulletin, Commonwealth Institute of Biological Control 5, 101-116.

Betbeder-Matibet, M. (1971) La lutte biologique contre Chilo sacchariphagus le 'borer ponctué de la canne à sucre à Madagascar L'Agronomie Tropicale 26, 332-336.

Betbeder-Matibet, M. (1977) Activités du laboratorre central d'entomologie de l'IRAT en matière de foreurs des gramınées. Bilans et objectifs. Réunion sur les foreurs des grammées. Bouaké, Côte d'Ivotre, 8-11 Novembre, 1-12

Bianchi, G., Baumgartner, J., Delucchi, V. \& Rahalivavololona, N. (1990) Modèle de population pour la dynamique de Maliarpha separatella Ragonot (Pyralıdae, Phycitınae) dans les rızıères malgaches du Lac Alaotra Journal of Applied Entomology 110, 384-397

Bianchi, G., Delucchi, V., Bousses, P. \& Rahalivavololona, N. (1991) La lutte biologique contre le borer blanc Africain du riz Maliarpha separatella Rag. à Madagascar. Etude de faisabilité rédigée à l'intention de la DDA. Berne - Institut de Phytiatrie, $E P F$, Zurch 1-71 (unpublished report).

Bianchi, G., Rasoloavisou, B. \& Genini, M. (in press) Noxiousness of the African white stem borer, Maliarpha separatella Rag. (Pyralıdae: Phycitınae) in irrigated paddy fields at Lake Alaotra (Madagascar). Insect Science and its Application.

Bin, F. \& Johnson, N.F. (1982) Some new species of Telenomus (Hymenoptera, Scelionidae) egg-parasitoids of tropical pyralid pests (Lepidoptera Pyralıdae). Redia 65, $229-252$

Bordat, D. (1979) Sondages effectués en Côte d'Ivorre concernant les foreurs du riz et leurs parasites IRAT Montpellier, France 1-40 (unpublished report).

Borror, D.J., Triplehorn, C.A. \& Johnson, N.F. (1989) An introduction to the study of insects 6th edn. $875 \mathrm{pp}$. Saunders College Publishing.

Bouček, Z. (1988) Australasıan Chalcıdoıdea. 832 pp. Wallingford UK, CAB International.

Bousses, P. \& Rahalivavololona, N. (1990) La lutte biologique contre le borer blanc africain Maluarpha separatella Rag. à l'aide de parasitoides exotiques. prospection faunistique dans les régions de Morondava et de Tanandava (Madagascar). Rapport du mission 19 août-2 septembre 1990, Projet 'Protection Intégrée en Riziculture', 1-16 (unpublished report)

Brenière, J., Rodriguez, H. \& Ranaisova, H. (1962) Un ennem1 de riz à Madagascar, Maliarpha separatella Rag. ou borer blanc. L'agronomie Tropicale 17, 223-302.

Brues, C.T. (1926) Studies on Ethopian Braconidae, with a catalogue of the African species. Proceedings of the American Academy of Arts and Sciences 61, 205-436.

CIE (Commonwealth Institute of Entomology) (1970) Maharpha separatella Ragonot. Distribution maps of pests, series $A$, no 271. Commonwealth Institute of Entomology, London.

Conlong, D.E. \& Graham, D.Y. (1988) A comparison of the known life histories of the bethylids Parasierola sp and
Gonozus natalensts Gordh collected from Eldana sacchanna Walker (Lepıdoptera: Pyralıdae) in Uganda and southern Africa respectively. Journal of the Entomological Society of Southern Africa 51, 143-144.

Conlong, D.E., Graham, D.Y. \& Hastings, H. (1988) Notes on the natural host surveys and laboratory rearing Goniozus natalensis Gordh (Hymenoptera- Bethylidae), a parasitord of Eldana saccharna Walker (Lepidoptera. Pyralıdae) larvae from Cyperus papyrus. Journal of the Entomological Society of Southern Africa 51, 115-127.

Coquard, J. (1987) Goniozus procerae biologie et fécondité en laboratoire. Mémoires et Travaux de l'IRAT 6, 1-44.

Cork, A., Agyen-Sampong, M., Fannah, S.J. Beevor, P.S. \& Hall, D.R. (1991) Sex pheromone of the female African white nce stem borer, Maliarpha separatella (Lep., Pyralıdae) from Sierra Leone: identification and field testing. Journal of Chemical Ecology 17, 1205-1217.

Delvare, G. (1988) Révision des Eurytoma (Hym: Eurytomidae) d'Afrique occidentale décrits par Risbec. Annales de la Société Entomologique de France (NS) 24, 117-149

Descamps, M. (1956) Insectes nuisibles au riz dans le nord Cameroun. L'Agronomie Tropicale 11, 732-755.

Dessart, P. (1971) Transferts génériques de quelques Céraphronidae (Hym Ceraphronoidea). Bulletm et Annales de la Soctété Royal d'Entomologie de Belgique 107, 94-100.

Doutt, R.L. \& Viggiani, G. (1968) The classification of the Trichogrammatidae (Hymenoptera: Chalcidordea). Proceedings of the California Academy of Sctences, Fourth Sertes 35, $477-586$.

Etienne, J. (1977) Lutte contre les foreurs des graminées à la Réunion IRAT-Réunion. Réunion sur les foreurs des graminées. Bouaké, Côte d'Ivoire, 8-11 Novembre, Annexe VI, $1-4$.

Etienne, J. (1987) Les problèmes entomologiques actuels en riziculture casamançaise. L'Agronomie Tropicale 42, 47-60.

Ferrière, C. (1933) Chalcidoid and proctotrupoid parasites of pests of the coconut palm Stylops 2, 86-108.

Gauld, I.D. \& Bolton, B. (Eds) (1988) The Hymenoptera. $332 \mathrm{pp}$ London, British Museum (Natural History)/Oxford Unversity Press.

Girling, D.J. (1977) Parasierola sp. (Hymenoptera. Bethylidae) a parasite of Eldana saccharina Wlk. (Lepidoptera- Pyralidae). Biological control of the stem-borer in Uganda. Entomologists' Monthly Magazine 113, 211-212.

Gordh, G. (1986) A new species of Goniozus Foerster 1851 from southern Africa parasitizing sugar cane borer, Eldana sacchanna Walker, and taxonomic notes on species of the genus in Africa (Hymenoptera: Bethylidae; Lepidoptera: Pyralidae). Journal of the Entomological Society of Southern Africa 49, $257-265$.

Gordh, G. \& Moczar, L. (1990) A catalog of the world Bethylidae (Hymenoptera: Aculeata). Memors of the American Entomological Institute 46, 1-364.

Graham, D.Y. \& Conlong, D.E. (1988) Improved laboratory rearing of Eldana saccharina Walker (Lepidoptera: Pyralıdae) and its indigenous parasitoid Gonozus natalensis (Hymenoptera. Bethylidae). Proceedings of the South African Sugar Technologists' Association 62, 116-119.

Graham, M.W.R. de V. (1991) A reclassification of the European Tetrastrichinae (Hymenoptera: Eulophidae): revision of the remaining genera. Memotrs of the American Entomological Institute 49, 1-322.

Granger, C. (1949) Braconides de Madagascar. Mémotres de l'Institut Sctentifique de Madagascar sér. A. 2, 1-428 
Gupta, V.K. (1987) The Ichneumonidae of the Indo-Australian area (Hymenoptera). Memoirs of the American Entomological Institute 41, 1-1210.

Haliday, A.H. (1834) Essay on the classification of parasitic Hymenoptera, etc. Entomological Magazine 2, 225-259.

Harris, K.M. (1962) Lepidopterous stem borers of cereals in Nigeria Bulletin of Entomological Research 53, 139-172

Ho, D.T. (1986) Damage and yield loss caused by stem borers in irrigated nce in Kenya. Tropical Agriculture 63, 201-204

Ho, D.T., Njokah, J.J. \& Kibuka, J.G. (1983) Studies on rice stem-borers in Kenya with emphasis on Malarpha separatella Rag. Insect Science and its Application 4, 65-73.

Horstmann, K. (1990) Die westpalaarktischen Arten der Gattung Pristomerus Curtis, 1836 (Hymenoptera, Ichneumonidae). Entomofauna, Zeitschrift fur Entomologie 11, 9-44.

Ingram, W.R. (1958) The lepidopterous stalk borers associated with Graminae in Uganda. Bulletm of Entomological Research 49, 367-383

Jordan, F.J. (1966) Report on an investigation into the presence and prevalence of rice stem-borers and their parasites in Sierra Leone, 1964-1965. West African Rice Research Station, Rokupr, Sierra Leone \& International Rice Research Institute, Los Baños, Philippines, 1-47 (unpublished report)

Kohl, F.F. (1906) Zoologische Ergebnisse der Expedition der Kanserlichen Akademe der Wisserischaften nach Sudarabien und Sokotra im Jahre 1898-1899. Hymenoptera. 1-133. Wien.

Lewvanich, A. (1981) A revision of the Old World species of Scirpophaga (Lepidoptera Pyralidae). Bulletin of the British Museum (Natural History) Entomology Series 42 , $185-298$

Li, C.S. (1985) Sugar cane insect pests with special reference to the moth borers in the Markham Valley, Papua New Guinea. Mush 50, 13-18

Ly, L.S. (1976) Etude morphologique et biologique de Gomozus procerae Risbec (Hymenoptera, Bethylidae) parasite de Chilo suppressalis (Walker) (Lepidoptera: Pyralidae). Faculté des Saences, Unversité de Paris VI. P \& $M$ Cure. 1-56.

Martin, E.L. (1958) Notes on some nce stem borers (Lepidoptera Pyralidae) with a description of a new species of Chilo Zincken. Bulletm of Entomological Research 49, 187-191

Mathez, F.C. (1972) Chilo partellus Swinh., C. onchalcoctiella Strand (Lep, Crambidae) and Sesama calamists [sic] Hmps. (Lep., Noctuidae) on maize in the Coast province, Kenya, Mittellungen der Schweizerischen Entomologischen Gesellschaft 45(4), $267-289$.

Muesebeck, C.F.W. (1940) Two new hymenopterous parasites of sugarcane borers in India. Proceedings of the Entomological Society of Washington 42, 120-122.

Narendran, T.C. (1989) Oriental Chalcididae (Hymenoptera: Chalcidordea). Zoological Monographs, Department of Zoology, Umversity of Calicut, Kerala, India 1-440

Ndoye, M. (1980) Gonizus procerae Rısbec (Hymenoptères, Bethylidae), ectoparasite larvaire d'Actgona tgnefisals Hampson (Lépidoptères, Pyralıdae, Crambinae). Bulletin de I'IFAN sér. A 42, 394-400.

Nixon, G.E.J. (1974) A revision of the north-western European species of the glomeratus-group of Apanteles Forster ( $\mathrm{Hy}$ menoptera, Braconidae). Bulletin of Entomological Research 64, $453-524$

Njokah, J.N. \& Okhoba, M.M. (1985) Key research areas on irrigated rice in Kenya. pp 91-96 in Rice improvement in eastern, central and southern Africa. Proceedings of the International Rice Workshop at Lisaka, Zambia April 9-19, 1984.
Overholt, W.A. (1993) Annual report 1992 classical biological control of Chlo partellus International Centre of Insect Physıology and Ecology/Wagenıngen Agricultural University 1-8 (unpublished).

Polaszek, A. (1992) Cereal stem borers and their parasitoids in Africa. Proceedings of the Section Experimental \& Apphed Entomology of the Netherlands Entomological Soctety 3, 70-71

Polaszek, A. \& Kimani, S.W. (1990) Telenomus species (Hymenoptera. Scelıondae) attackıng eggs of pyralıd pests (Lepidoptera) in Africa. a review and guide to identification Bulletin of Entomological Research 80, 57-71

Polaszek, A., Ubeku, J.A. \& Bosque-Perez, N.A. (1993) Taxonomy of the Telenomus busselae species-complex (Hymenoptera. Scelıondae) egg parasitords of cereal stem borers (Lepidoptera Noctuidae, Pyralidae) Bulletin of Entomological Research 83, 221-226

Pollet, A. (1981) Malarpha separatella (Ragonot) (Pyralıdae. Phycitınae) sur riz irngué en Côte d'Ivorre Centrale (Kotıessou). données biologiques et mécanısmes régulateurs des populations naturelles Travaux et Documents de I'ORSTOM 140, $230 \mathrm{pp}$.

Quartey, S.Q. (1975) The bulogy of leptdopterous stemborers of nce in eastern Ghana MSc Thesis, University of Ghana (Legon)

Risbec, J. (1950) Etat actuel des recherches entomologiques agricoles dans la régıon correspondant au secteur soudanais de rechereches agronomiques Compte Rendus Ier Conference Internationale Afruanistes de l'Ouest 1, 317-375

Risbec, J. (1950a) Les parasites des insectes borers du riz au Cameroun L'Agronomie Tropicale 11, 234-247

Risbec, J. (1956b) Hyménoptères parasites du Cameroun (2e contribution) Bulletin de l'Institut Francaise de l'Afrique Noire, Dakar (A) 18,97-164

Risbec, J. (1950c) Hyménoptères du Cameroun (3e contribution) Bulletin de l'Institut Françase de l'Afrique Norre, Dakar $(A) \mathbf{1 8 .}$ 806-833.

Roudeillac, P. (1972) Résultats des prospectıons entomologıques effectuées en Casamance Situation de l'entomofaune nuisible et parasitaire sur riz durant l'année 1972 Centre de Recherches Agncoles de Dibelor, Ziguinchor, Senegal, 1-8 (unpublished report).

Sandhu, G.S. \& Chander, R. (1975) Occurence of green striped borer Maltarpha separatella Ragonot on sorghum in the Punjab. Joumal of the Bombay Natural History Society 72 , $872-873$.

Sarhan, A.A. \& Quicke, D.L.J. (1990) Mesobraconordes psolopterus (Hymenoptera. Braconidae), a larval parasitord of the white nce borer, Maliarpha separatella (Lepidoptera: Pyralıdae), in West Africa. Bulletin of Entomological Research 80, 217-222

Scheibelreiter, G.K. (1972) Quarterly reports I-4 CIBC (Commonwealth Institute of Biological Control) Ghana Station. (unpublished)

Seyrig, A. (1952) Les ichneumonides de Madagascar IV Ichneumonidae Cryptinae. Mémorres de l'Académie Malgache 19. $1-213$.

Steffan, J.R. (1951) Contribution à l'étude des Haltıchellinae 'groupe Euchalcudia' [Hymenopt Chalcıdıdae] conservés au Muséum National d'Historre Naturelle de Parıs. Mémotres Muséum de l'Histurre Naturelle Paris, (N.S.) Zoologie 4, 51-86.

Szépligeti, G. (1911) Braconidae der I Zentral-Afrika-Expedition. Wissenschaftiche Ergebnisse der Deutsches Zentral-AfrikaExpedition 1907-1908 3, 393-418.

Townes, H. (1970) Genera of Ichneumonidae Part 2 Gelinae. Memours of the American Entomological Society 12, I-537. 
Townes, H. \& Townes, M. (1973) A catalogue and reclassification of the Ethiopian Ichneumonidae Memoirs of the American Entomological Society 19, 1-416

Tran, V.L. (1977) Les ravageurs du riz en Côte d'Ivoire. Systématique des espèces et de leurs parasites. Biologie de Chilo diffusilıneus (J. de Joannus) et de Chilo zacconus Bleszynskı (Lepıdoptera, Pyralidae) Thèse de Doctorat de 3e cycle, Univ. Paris VI

Vercambre, G. (1977a) 1 Recherches effectuées sur les foreurs nz ırrigué en Casamance (synthèse des résultats obtenus) Réumon sur les foreurs des graminées. Bouaké, Côte d'Ivoire, 8-11 Novembre, Annexe XI, 1-10.

Vercambre, B. (1977b) Premières recherches en vue d'une lutte biologique contre les insectes nuisibles au riz irrigué au
Sénégal. ADRAO/WARDA seminar on Plant Protection for the Rice Crop, Monrovia, Liberia. 1-6.

Viggiani, G. (1969) Ricerche sugli Hymenoptera Chalcidoidea XXII. Ridescrizione dei Trıchogrammatıdae descritti da J. Risbec. Bollettmo del Laboratorio di Entomologia Agraria 'Filippo Stlvestri' 27, 187-209.

Wilkinson, D.S. (1927) Eight new species of Braconidae Bulletm of Entomological Research 18, 33-46.

Wilkinson, D.S. (1931) Four new species of Ichneumonoidea. Bulletin of Entomological Research 22, 393-397

(Accepted 25 November 1993) C. CAB INTERNATIONAL, 1994 